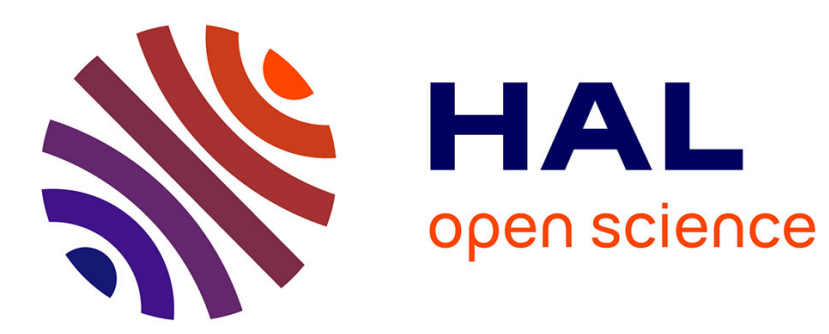

\title{
Earthquake Geology of the Bulnay Fault (Mongolia)
}

Magali Rizza, J.F. Ritz, C. Prentice, R. Vassalo, Regis Braucher, C. Larroque, A. Arzhannikova, S. Arzhannikov, S. Mahan, M. Massault, et al.

\section{To cite this version:}

Magali Rizza, J.F. Ritz, C. Prentice, R. Vassalo, Regis Braucher, et al.. Earthquake Geology of the Bulnay Fault (Mongolia). Bulletin of the Seismological Society of America, 2015, 105 (1), pp.72-93. 10.1785/0120140119 . hal-01179837v2

\section{HAL Id: hal-01179837 https://hal.science/hal-01179837v2}

Submitted on 30 Jan 2017

HAL is a multi-disciplinary open access archive for the deposit and dissemination of scientific research documents, whether they are published or not. The documents may come from teaching and research institutions in France or abroad, or from public or private research centers.
L'archive ouverte pluridisciplinaire HAL, est destinée au dépôt et à la diffusion de documents scientifiques de niveau recherche, publiés ou non, émanant des établissements d'enseignement et de recherche français ou étrangers, des laboratoires publics ou privés. 


\title{
Earthquake Geology of the Bulnay Fault (Mongolia)
}

\author{
by M. Rizza, J.-F. Ritz, C. Prentice, R. Vassallo, R. Braucher, C. Larroque, A. Arzhannikova, \\ S. Arzhannikov, S. Mahan, M. Massault, J.-L. Michelot, M. Todbileg, and ASTER Team
}

\begin{abstract}
The Bulnay earthquake of 23 July $1905\left(M_{\mathrm{w}} 8.3-8.5\right)$, in north-central Mongolia, is one of the world's largest recorded intracontinental earthquakes and one of four great earthquakes that occurred in the region during the twentieth century. The $375 \mathrm{~km}$ long surface rupture of the left-lateral, strike-slip, N095 E-trending Bulnay fault associated with this earthquake is remarkable for its pronounced expression across the landscape and for the size of features produced by previous earthquakes. Our field observations suggest that in many areas the width and geometry of the rupture zone is the result of repeated earthquakes; however, in those areas where it is possible to determine that the geomorphic features are the result of the 1905 surface rupture alone, the size of the features produced by this single earthquake are singular in comparison to most other historical strike-slip surface ruptures worldwide. Along the $80 \mathrm{~km}$ stretch, between $97.18^{\circ} \mathrm{E}$ and $98.33^{\circ} \mathrm{E}$, the fault zone is characterized by several meters width and the mean left-lateral 1905 offset is $8.9 \pm 0.6 \mathrm{~m}$ with two measured cumulative offsets that are twice the 1905 slip. These observations suggest that the displacement produced during the penultimate event was similar to the 1905 slip. Morphotectonic analyses carried out at three sites along the eastern part of the Bulnay fault allow us to estimate a mean horizontal slip rate of $3.1 \pm 1.7 \mathrm{~mm} / \mathrm{yr}$ over the Late Pleistocene-Holocene period. In parallel, paleoseismological investigations show evidence for two earthquakes prior to the 1905 event, with recurrence intervals of $22700-4000 \mathrm{yrs}$.
\end{abstract}

Online Material: Table of ${ }^{10} \mathrm{Be}$ concentrations with sampling information, highresolution stratigraphic and topographic maps, and ${ }^{10} \mathrm{Be}$ analyses at various sites.

\section{Introduction and Tectonic Setting}

Between 1905 and 1957, four $M \sim 8$ earthquakes occurred in western Mongolia and the adjacent area within China (Molnar and Deng, 1984; Baljinnyam et al., 1993; Schlupp, 1996), making this region one of the most tectonically active intracontinental domains in the world (Fig. 1a). Considering the high rate of large earthquakes between 1905 and 1957, these earthquakes have been described as a seismic cluster involving mechanical coupling between faults (Chéry et al., 2001; Pollitz et al., 2003; Vergnolle et al., 2003). These earthquakes occurred along strike-slip faults that are several hundred kilometers long (i.e., Tsetserleg, Bolnay, Fuyun, and Bogd faults) and accommodate the northernmost deformation related to the India-Asia collision (Florensov and Solonenko, 1965; Molnar and Tapponnier, 1977; Tapponnier and Molnar, 1979; Cunningham, 1998). These surface rupture patterns have been described by several morphotectonic studies show-

*Now at Aix-Marseille Unisité, CNRS-IRD-Collège de France, CEREGE UMR 34, BP80 13545 Aix en Provence, France; rizza@cerege.fr. ing that these active faults have millimetric slip rates over periods of $10^{4}-10^{5} \mathrm{ka}$ (Ritz et al., 1995, 2003, 2006; Walker et al., 2006; Vassallo et al., 2007; Nissen, Walker, Bayasgalan, et al., 2009; Nissen, Walker, Molor, et al., 2009; Rizza et al., 2011). Geodetic measurements (Global Positioning System [GPS]) within Mongolia and the surrounding areas confirm that contemporary crustal deformation is distributed across north-northwest-striking dextral strike-slip faults in the Altay range and east-west left-lateral strike-slip faults in central and eastern Mongolia (Calais et al., 2003; Vergnolle, 2003) (Fig. 1). Paleoseismological investigations along the Gurvan Bogd fault system, which ruptured in 1957 during the GobiAltay earthquake, have shown long recurrence intervals of 3-5 ky for large earthquakes (Schwartz et al., 1996, 2007; Prentice et al., 2002; Rizza, 2010).

In 1905, two major earthquakes with magnitude $M>7.5$ occurred in the northern part of the Hangay massif (Fig. 1a). The 9 July 1905 Tsetserleg earthquake $\left(M_{\mathrm{w}} 8.0\right.$, $49.5^{\circ} \mathrm{N}, 97.3^{\circ} \mathrm{E}$ ), which produced an $\sim 130 \mathrm{~km}$ long surface rupture, trending $60^{\circ} \mathrm{N}$ (Khil'ko et al., 1985; Baljinnyam 
(a)

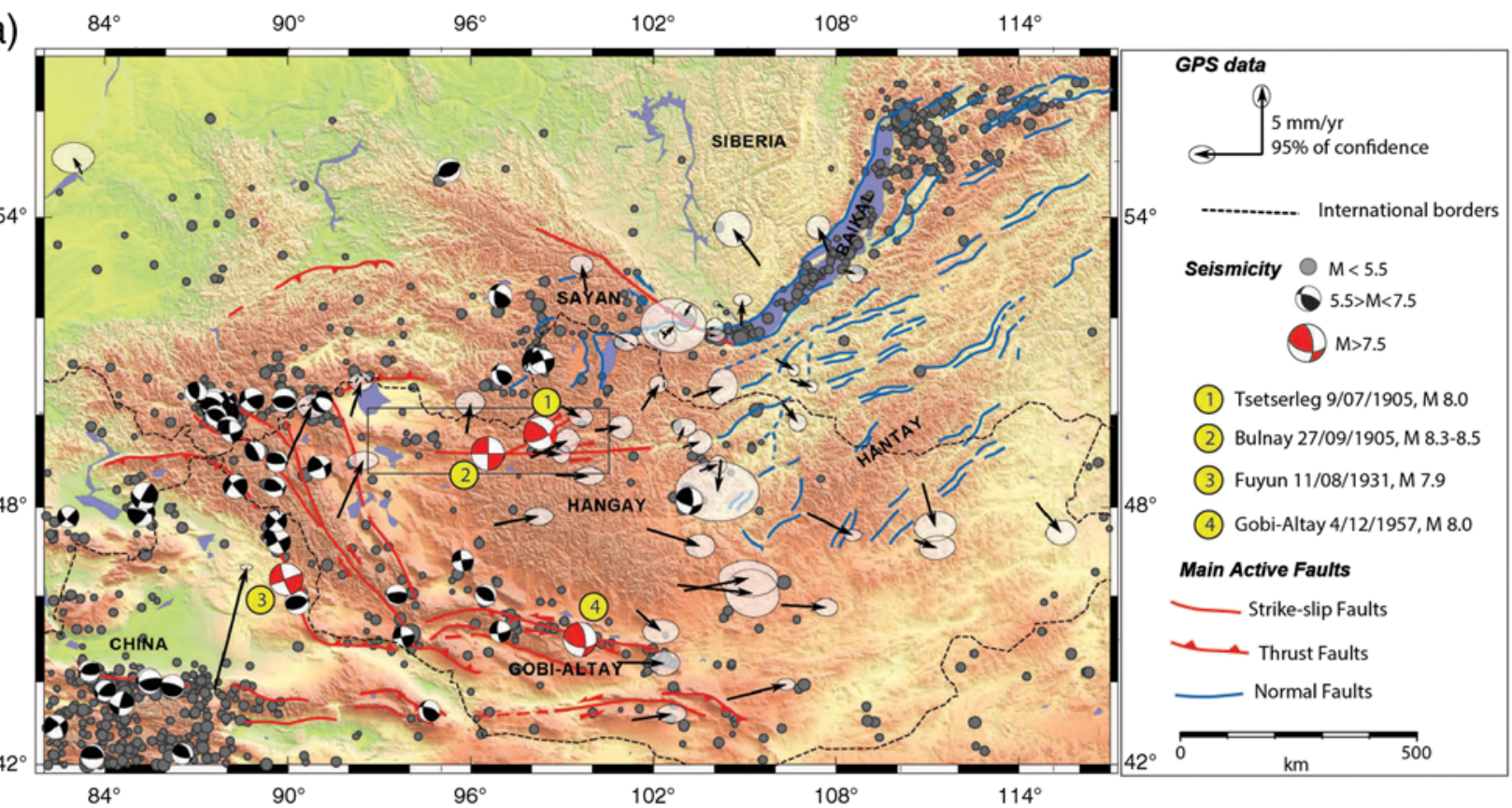

(b)

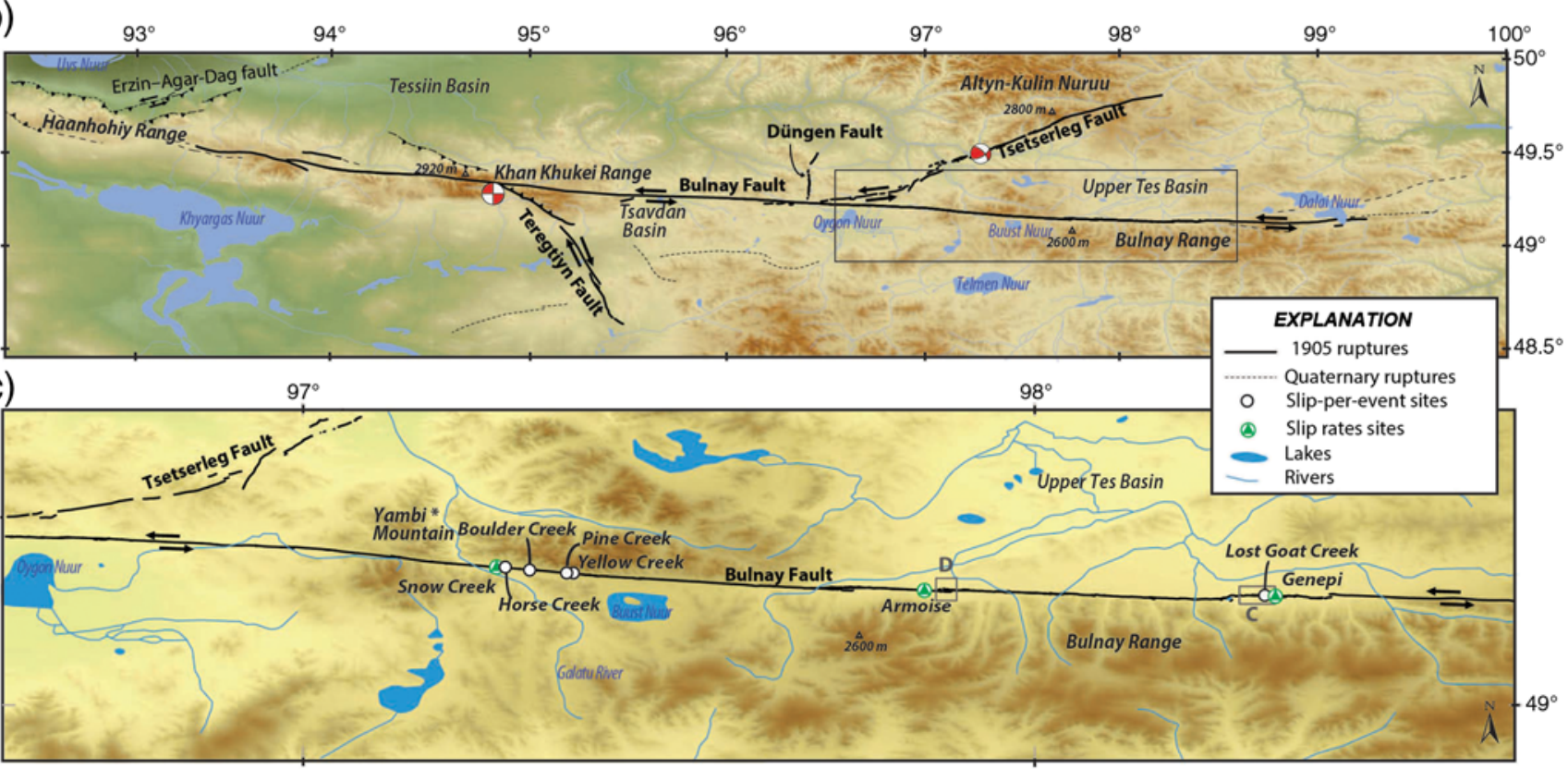

Figure 1. (a) Tectonic setting of Mongolia. Active strike-slip and reverse faults are mapped; reverse faults (lines with teeth) on upper plate and active normal faults are shown. The black arrows are geodetic vectors from Calais et al. (2003), with white ellipses representing 95\% confidence limits. The gray dots show earthquake epicenters from 1980 to 2008. Black centroid moment tensor solutions are from the Global Centroid Moment Tensor Catalog (see Data and Resources). Four major earthquakes occurred during the twentieth century and are represented by the centroid moment tensor solutions labeled 1 to 4 (from Schlupp and Cisternas, 2007, and Okal, 1976). The rectangle shows the area enlarged in (b). (b) Locations of the 1905 surface ruptures along the Tsetserleg, Bolnay, Teregtyin, and Düngen faults (modified from Baljinnyam et al., 1993, and Schlupp and Cisternas, 2007) from our own mapping. The base map is from ASTER digital elevation models (DEMs) (see Data and Resources). The rectangle shows the area enlarged in (c). (c) Portion of the Bolnay fault surveyed in this study, with locations of the study sites discussed in text (dots and triangles). Rectangles C and D show locations of Figures 5 and 6, respectively. The color version of this figure is available only in the electronic edition.

et al., 1993; Schlupp and Cisternas, 2007). Fourteen days later, the Bulnay earthquake $\left(49.2^{\circ} \mathrm{N}, 94.8^{\circ} \mathrm{E}\right)$ occurred at the intersection between the main left-lateral, strike-slip Bulnay fault and the right-lateral, strike-slip Teregtyin fault
(Khil'ko et al., 1985; Baljyniiam et al., 1993). The moment magnitude $\left(M_{\mathrm{w}}\right)$ of the Bulnay earthquake is estimated to be between 8.3 and 8.5 using body waveform inversion (Schlupp and Cisternas, 2007), making it one of the largest 
known historic earthquakes in an intracontinental domain. The $375 \mathrm{~km}$ long surface rupture was bilateral, propagating $100 \mathrm{~km}$ to the west and $275 \mathrm{~km}$ to the east along the main Bulnay fault (Schlupp and Cisternas, 2007). In addition, approximately $100 \mathrm{~km}$ of surface rupture occurred along the associated Teregtyin $\left(80 \mathrm{~km}\right.$, striking $\left.135^{\circ} \mathrm{N}\right)$ and Düngen $\left(20 \mathrm{~km}\right.$, striking $\left.0^{\circ} \mathrm{N}\right)$ faults (Fig. 1b).

The first observations of the Bulnay fault surface ruptures were made less than 10 yrs after the 1905 earthquake by Voznesenskii (1962) and were resurveyed later by Khil'Ko et al. (1985) and Baljynniam et al. (1993). The surface rupture of the 1905 Bulnay earthquake is complex and includes such large-scale features as tension gashes that are tens of meters long, and mole tracks and depressions that are several tens of square meters in width and a few meters in height. These features are described along the entire surface rupture (Baljinnyam et al., 1993; Schwartz et al., 2009). The 1905 coseismic offsets reported along the main fault range from $8 \pm 2 \mathrm{~m}$ to $11 \pm 2 \mathrm{~m}$ between the eastern termination of the fault and the junction between the Bulnay and Teregtyin faults and decrease in the western part of the fault to $5 \pm 2 \mathrm{~m}$ (Voznesenskii, 1962; Florensov and Solonenko, 1965; Baljinnyam et al., 1993; Schwartz et al., 2009). No geological slip rates have been estimated for the Bulnay fault. GPS measurements indicate a strain accumulation rate of $2.6 \pm 1 \mathrm{~mm} / \mathrm{yr}$ (Calais et al., 2003; Vergnolle et al., 2003). A limited paleoseismic investigation at one site along the western part of the fault, between the Tsavdan basin and the Khan Khukei range, suggests that the penultimate earthquake on this segment occurred between 2480 and 3270 cal B.P. (Schwartz et al., 2009).

We investigated the surface rupture of the main leftlateral, strike-slip Bulnay fault using satellite imagery and aerial photographs and conducted field studies along the eastern part of the 1905 rupture, between $97.18^{\circ} \mathrm{E}$ and $98.33^{\circ} \mathrm{E}$ (Fig. 1c). The goals of our field investigations were to determine geological slip rates and earthquake recurrence intervals using morphotectonic and paleoseismologic analyses. We documented the fault morphology along the Bulnay rupture and measured both the coseismic slip associated with the 1905 earthquake and the offsets that represent accumulated slip produced by multiple earthquakes. In addition, we determined slip rates at three sites using morphological analysis, in situ produced cosmogenic radionuclides, and optically luminescence techniques to date well-preserved offset streams and alluvial surfaces. We also excavated trenches across the fault to determine the times of prehistoric surface-rupturing earthquakes.

\section{Geomorphology of the Bulnay Fault Zone and 1905 Coseismic Slip}

The left-lateral Bulnay fault trends approximately $90^{\circ} \mathrm{N}$ and is clearly visible on both Landsat (15 m resolution) and SPOT-5-THR (2.5 m resolution) satellite images. The fault orientation is influenced by ancient faults related to the
Caledonian and Variscan orogenic cycles, which were reactivated in the late Cenozoic during the north-northeastsouth-southwest compression associated with the India-Asia collision (Sengör et al., 1993, Cunningham, 1998). The Bulnay fault traverses massifs composed of metamorphic and plutonic rocks, with colluvial deposits and fine-grained alluvial deposits underlying the slopes and foothills.

From longitude $93.5^{\circ}$ to $99^{\circ} \mathrm{E}$, geomorphic offsets on the Bulnay fault indicate that the sense of shear is purely left lateral. West and east of Buust Nuur lake (Fig. 1b), we observed meter- to kilometer-scale cumulative left-lateral displacements offsetting the pre-existing topography. The largest displacement we identified is west of Buust Nuur where both the Galutu river and the eastern edge of Yambi mountain (a Devonian granitic massif) are left-laterally displaced by $4 \pm 0.5 \mathrm{~km}$ (Fig. 2). We did not observed larger displacement elsewhere along the Bulnay fault and thus interpret this offset as the total cumulative left-lateral displacement across the fault. However, in places, for example between $92.5^{\circ} \mathrm{E}$ and $93.5^{\circ} \mathrm{E}$ within its western termination zone (Haanhohiy range), the topography is associated with a significant reverse component of slip accommodated across a young restraining bend massif (e.g., Cunningham, 2007) located south of Uvs Nuur.

The geometry of the surface faulting and the presence of large mole track features associated with the surface rupture make measurement of the 1905 left-lateral slip difficult. Along most of the Bulnay fault, it is difficult to distinguish between features produced in 1905 and features produced by previous earthquakes (Fig. 3). To assist with our mapping, we surveyed several sites along the fault using a Trimble kinematic GPS. Figure 4 shows several views of the fault and associated pressure ridges, pull-apart basins, and tension gashes near the western end of our field area, east of Yambi Mountain (see Fig. 1c for locations).

The morphology of the surface rupture appears to be related to the geological and structural setting. Between $97.69^{\circ} \mathrm{E}$ and $97.18^{\circ} \mathrm{E}$ (Fig. 1c), the Bulnay fault crosses a mountainous area where the fault is characterized by a narrow zone less than a few tens (5-10) of meters wide. Where the fault crosses large alluvial surfaces, the rupture pattern is more distributed. For instance, between $98.33^{\circ} \mathrm{E}$ and $97.69^{\circ} \mathrm{E}$, the Bulnay fault cuts through alluvial surfaces and the rupture pattern is characterized by systems of en echelon ruptures with individual segments that are several tens to hundreds of meters in length and several tens (20-50) of meters wide, mole tracks and tension gashes of up to several meters wide, fissures, and stepover zones between the individual ruptures (Fig. 4). Figure 5 illustrates the complexity of the rupture surface pattern where the fault traverses an alluvial surface between the Genepi and Double Pond sites. At this location, we mapped the surface pattern of the Bulnay fault using SPOT imagery with $2.5 \mathrm{~m}$ resolution and Google Earth imagery (DigitalGlobe images from May 2006) along a $3.8 \mathrm{~km}$ long section of the surface rupture. Between the Double Pond and Lost Goat Creek sites, the surface faulting is distributed across a width of $20 \mathrm{~m}$ and consists 


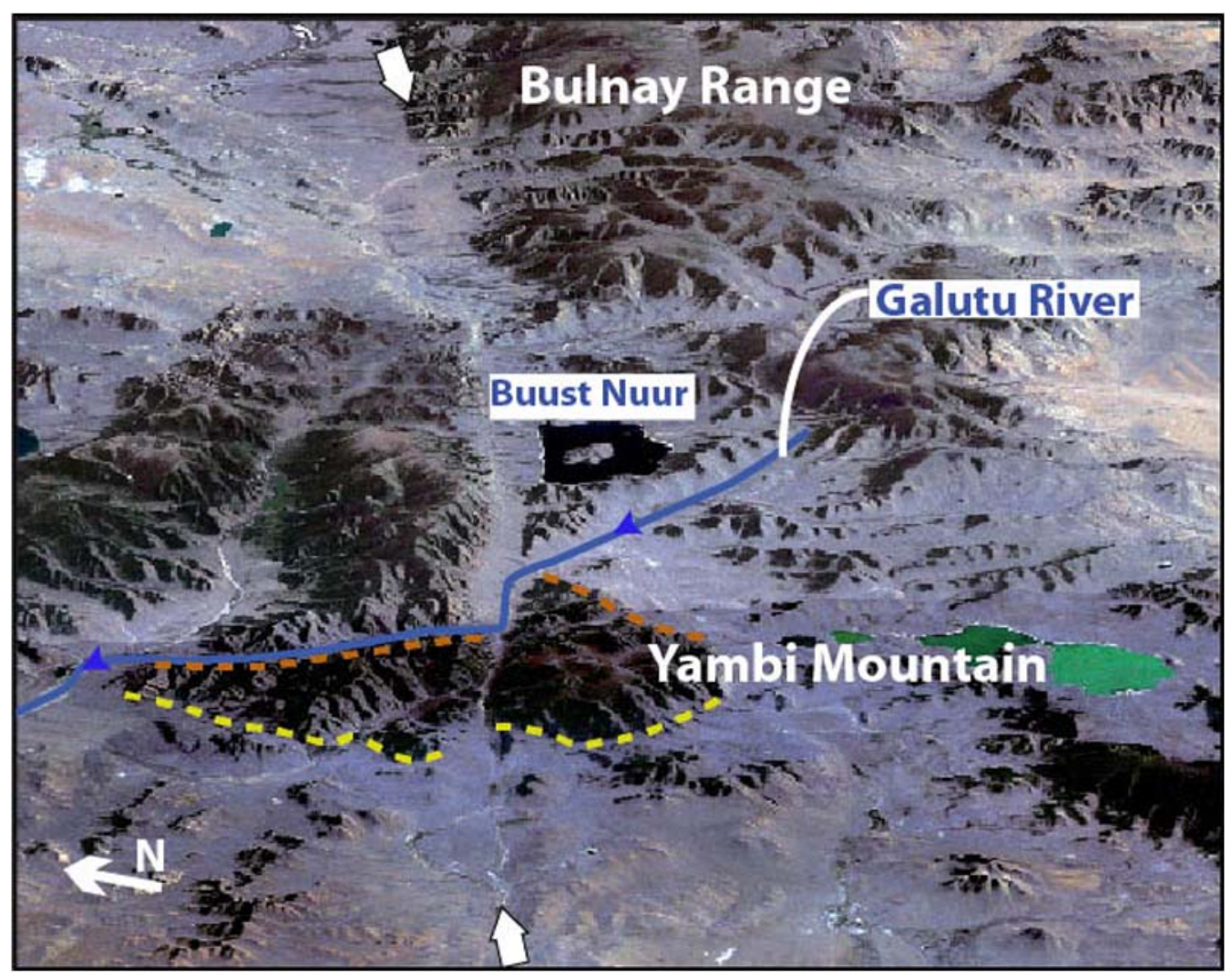

Figure 2. Perspective view looking east of the eastern part of the Bulnay fault (SPOT image). The Galutu River is left-laterally displaced along the fault zone (white arrows), and Yambi Mountain is delimited by the dashed lines. The color version of this figure is available only in the electronic edition.

of two parallel fault strands $100 \mathrm{~m}$ apart. Between the two fault traces, we observed large tension gashes that are oriented at an angle of $60^{\circ}$ with respect to the principal east-west-trending main faults. Thus, our observations raise the question of whether the morphology of the Bulnay surface is controlled in part by the near-surface lithology, with narrower and less distributed surface rupture where the fault breaks though crystalline rock near the surface, and a wider surface rupture more related to a spread out zone where the fault breaks through thick alluvial sediments.

At a number of sites along the Bulnay fault, we found evidence that the geomorphic features associated with the Bulnay fault represent the accumulation of slip produced in several earthquakes. A noticeable example can be found $8 \mathrm{~km}$ east of the Armoise Creek site, where a $500 \mathrm{~m} \times 300 \mathrm{~m}$ pullapart basin is associated with normal scarps and tension gashes that are several hundred meters long (Fig. 6). In some places within the graben, it is possible to distinguish the 1905 surface rupture, comprising fresh, steep slopes along the larger, cumulative fault scarps (left side of Fig. 6c). We interpret this graben to have resulted from repeated surface rupture.

Several offset streams record the displacement associated with the 1905 earthquake. We used kinematic GPS to make detailed maps of four offsets, which are presented in the
(E) appendix (available in the electronic supplement to this article); locations are shown in Figure 1c (Đ) see also Fig. S1). Our offset measurements were made on sites where stream incisions and risers are well linked on both sides of the fault zone. After having identified the fault line and the stream channels on the corresponding digital elevation models, we reconstructed the initial geometry of markers (stream axis and risers), back-sliding and aligning them on both sides of the fault. From these reconstructions, we estimated minimum and maximum slip offsets matching horizontal displacements.

The offset measurements presented in Table 1 correspond to mean values for each piercing point with their associated uncertainties (standard deviation at $1 \sigma$ ). In summary, between $97.69^{\circ} \mathrm{E}$ and $97.18^{\circ} \mathrm{E}$, the mean offset associated with the 1905 earthquake is $8.9 \mathrm{~m}(+1.2 \mathrm{~m},-1.0 \mathrm{~m})$. In two places, we found streams that appear to record an earlier displacement in addition to the 1905 offset at Pine Creek and Boulder Creek (see Table 1 and Fig. 7). As described in the Paleoseismic Investigations at Pine Creek (97.36 E) section, the Pine Creek site confirms the occurrence of two events since incision of the offset channel. The two cumulative displacements have a mean value of $17 \mathrm{~m}(+1.5,-1.3 \mathrm{~m})$, which is approximately twice the 1905 offset and suggests that slips per event are similar along this section of the Bulnay fault. 
(a)

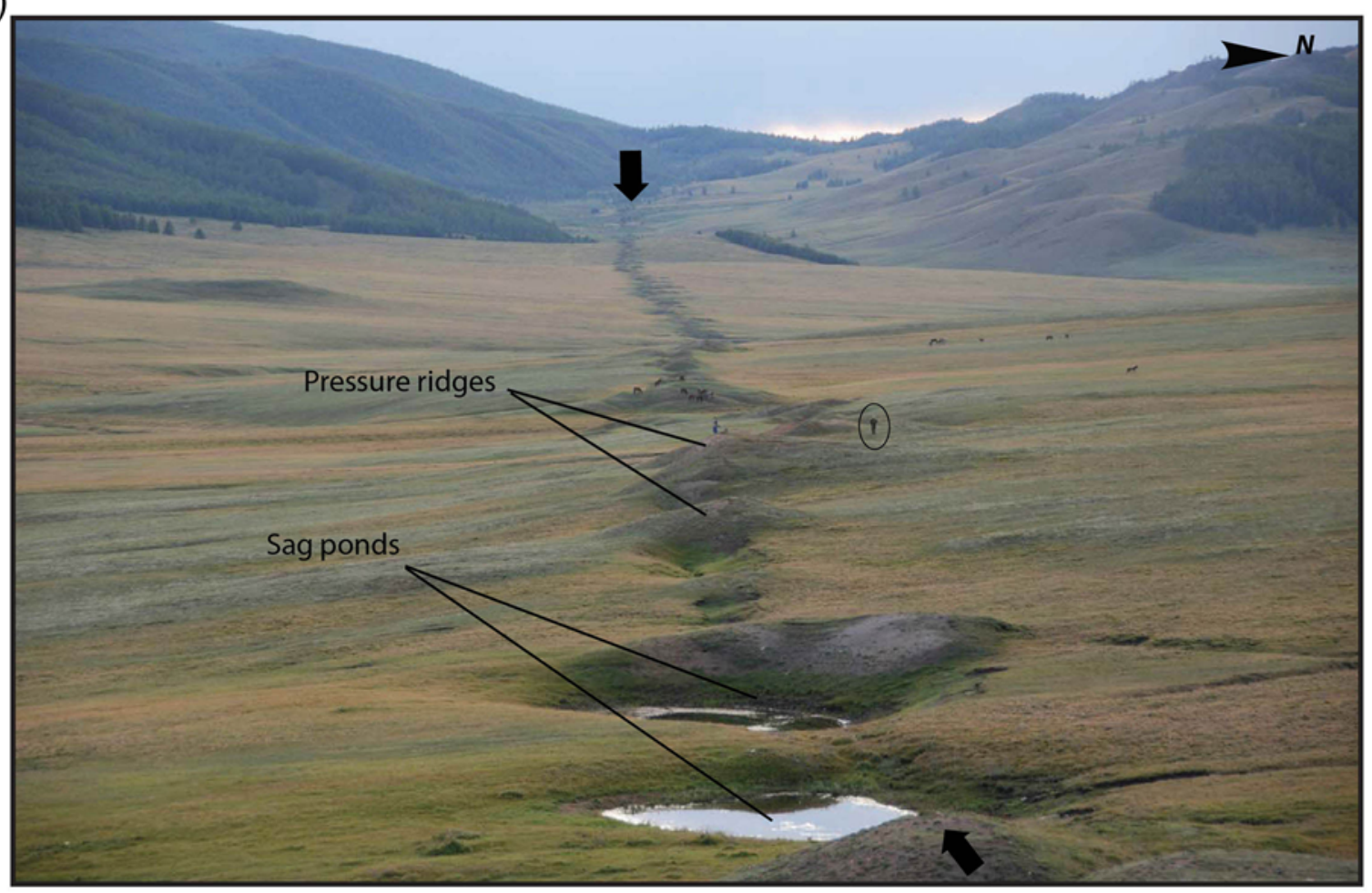

(b)

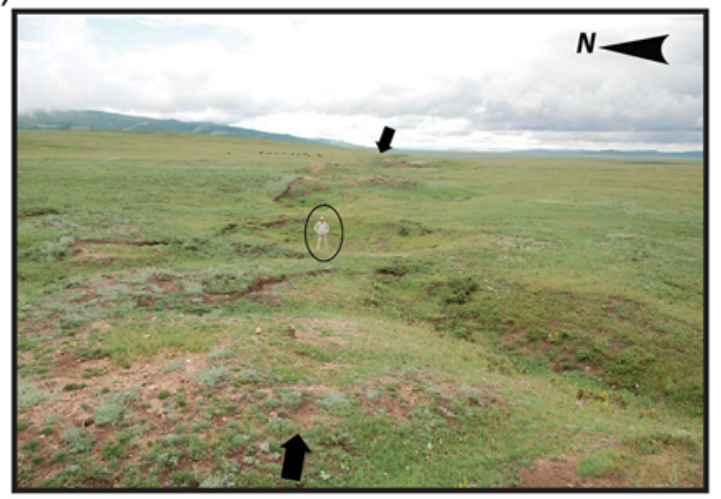

(c)

(d)

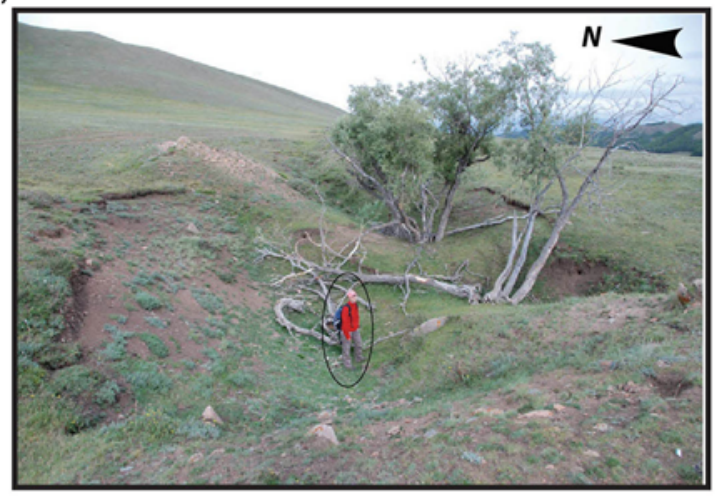

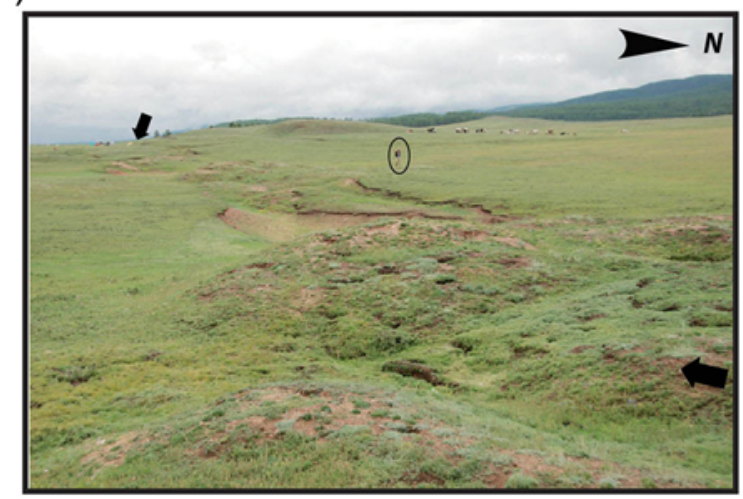

(e)

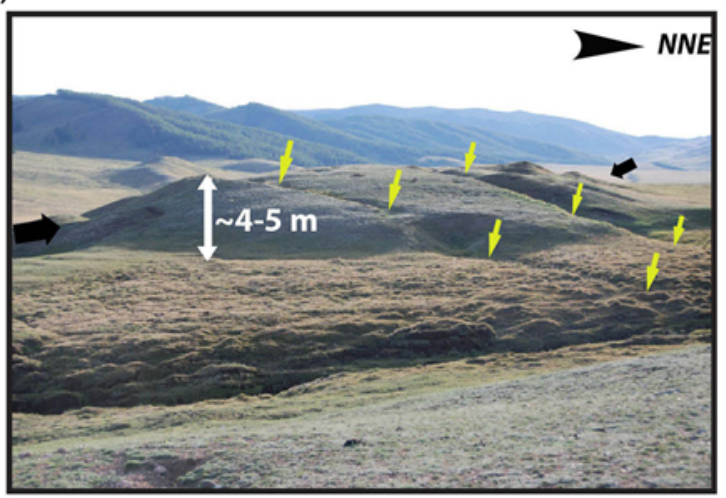

Figure 3. Field photographs of the Bulnay rupture taken in 2009. Ovals indicate people (for scale), and heavy black arrows indicate the fault trace. (a) Field view looking west of the Bulnay surface rupture between the Snow Creek and Western Creek sites. (b) Photograph looking east along the surface rupture between Genepi and Double Pond (see location in Fig. 5) showing the mole track morphology. (c) Photograph looking west along the surface rupture near Genepi. (d) Photograph showing the 1905 surface rupture between Snow Creek and Pine Creek, with trees growing in tension gashes. (e) Photograph looking west of a mole track affected by large tension gashes (light arrows) near the Snow Creek site. The color version of this figure is available only in the electronic edition. 
(a)

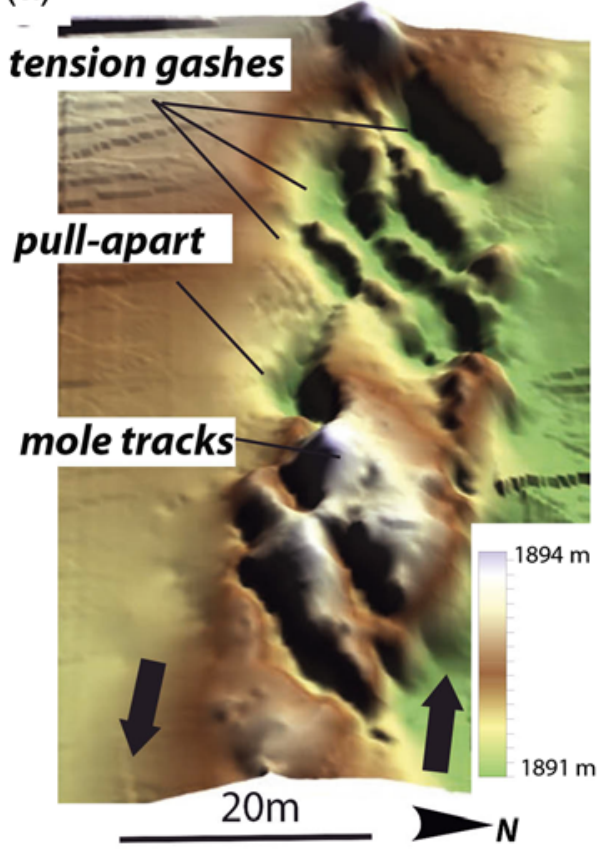

(b)

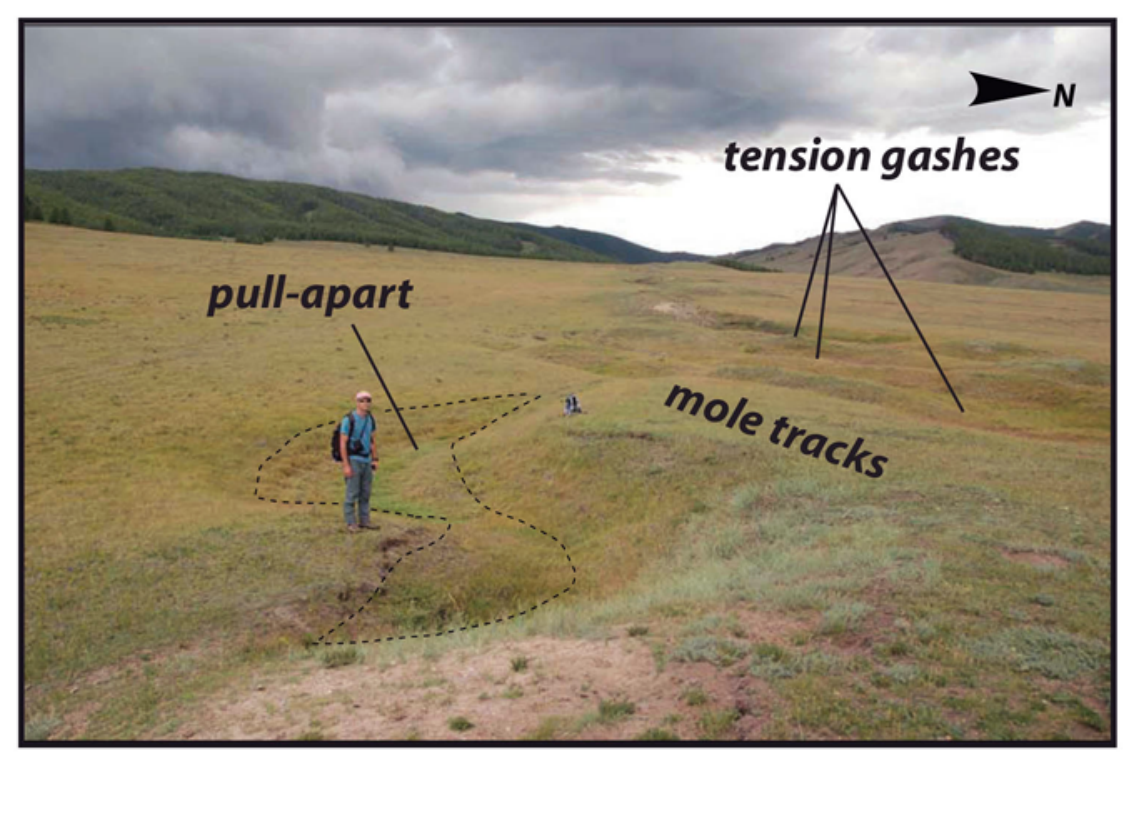

(c)

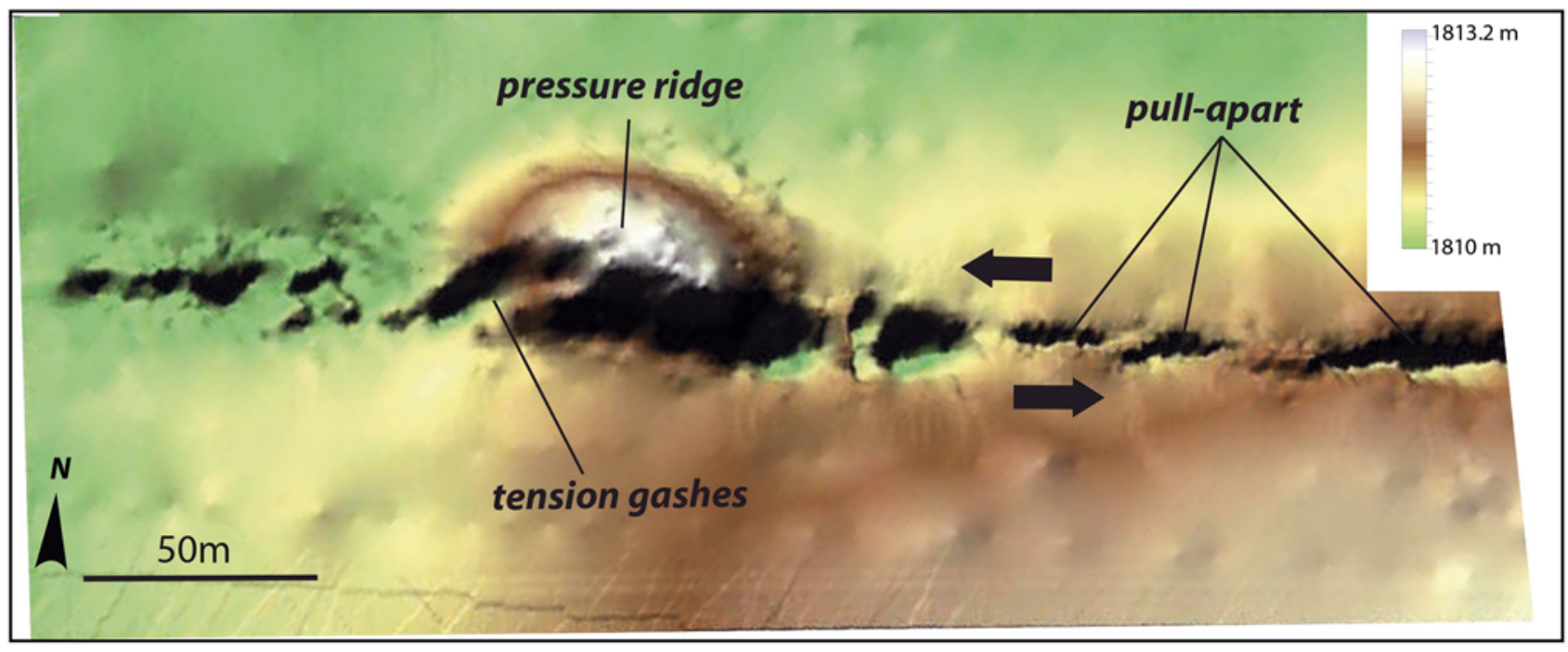

Figure 4. DEMs and perspective views of the Bulnay fault morphology produced from our (RTK) surveys. (a) Perspective view of the Bulnay fault zone showing the complexity of the ground ruptures near Snow Creek. In this area, tension gashes, mole tracks, and a pull-apart basin are interconnected, showing the complexity of the fault zone due to the accumulation of multiple quaternary surface ruptures. The tension gashes disrupt a pre-existing mole track from a previous earthquake. (b) Field photograph looking west of the zone surveyed by the kinematic Global Positioning System in (a). (c) Perspective view of the fault zone near Double Pond showing several pull-apart basins and a large and older pressure ridge cut by large tension gashes created during the 1905 earthquake. The color version of this figure is available only in the electronic edition.

\section{Slip Rate Estimates}

To estimate the horizontal slip rate along the Bulnay fault, we carried out morphotectonic analyses at the Genepi, Armoise, and Snow Creek sites, which we identified using SPOT imagery and aerial photographs. We used kinematic GPS surveys to quantify the cumulative displacements of streams incised into alluvial surfaces. In parallel, we col- lected samples from soil pits excavated into the alluvial surfaces to determine their ages using both in situ produced beryllium-10 ( ${ }^{10} \mathrm{Be}$; e.g., Ritz et al., 1995; Braucher et al., 1998; Siame et al., 2004; Vassallo et al., 2007) and luminescence techniques (Vassallo et al., 2005; LeDortz et al., 2009; Nissen, Walker, Molor, et al., 2009; Rizza et al., 2011).

Unfortunately, although we carried out sampling and analysis of the ${ }^{10} \mathrm{Be}$ samples following established protocols 

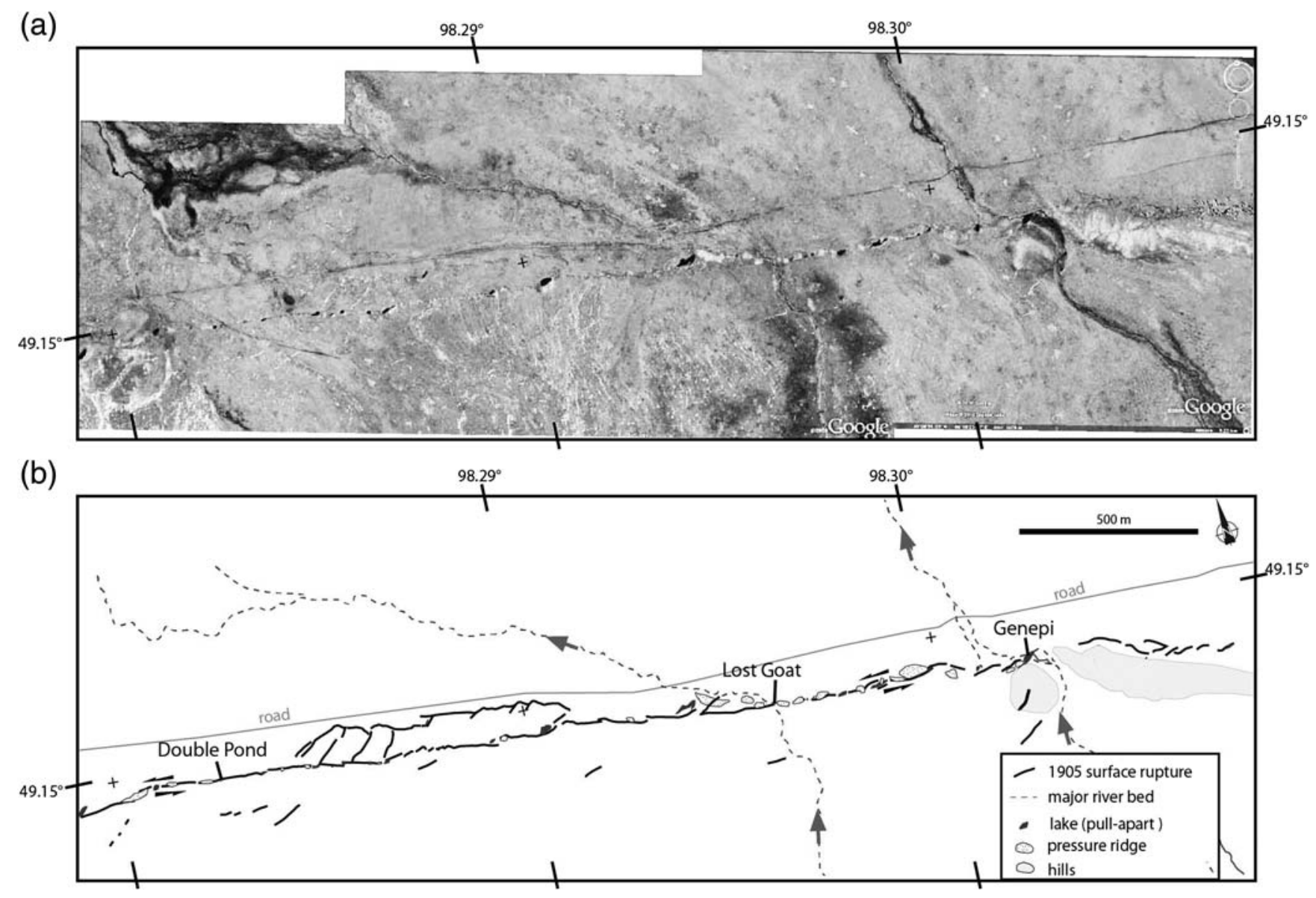

Figure 5. Morphology of the Bulnay fault between Genepi and Double Pond sites. The location is shown as rectangle C in Figure 1c. (a) Google Earth view (see Data and Resources) of the surface rupture. The snow highlights the morphology of the fault zone and the drainage network within the alluvial plain. (b) Interpretation of the area shown in (a), with surface ruptures indicated by lines. Note the system of pressures ridges and pull-aparts (lakes) corresponding to fault stepovers. The morphology of the Bulnay fault is wider between Lost Goat and Double Pond sites with two fault segments and large fissures.

(e.g., Ritz et al., 2006, and Braucher et al., 2011), the resulting ${ }^{10} \mathrm{Be}$ data are difficult to interpret without making numerous assumptions that cannot be tested, and therefore the ${ }^{10} \mathrm{Be}$ analyses are not useful for inferring surface ages. Our explanation for the problems with the ${ }^{10} \mathrm{Be}$ data is that the fans are composed of a multilayered stratigraphy that records successive exposure episodes and that drainage networks in this region have evolved, delivering sediments to the fans from a wide variety of sources. Our data suggest that the complexity of the surface processes in this environment precludes the use of ${ }^{10} \mathrm{Be}$ for surface exposure dating. (E) We therefore do not use the ${ }^{10} \mathrm{Be}$ data to calculate slip rates, but for the sake of completeness we provide them in the electronic supplement.

In contrast to the ${ }^{10} \mathrm{Be}$ data, the optically stimulated luminescence (OSL) analyses of the youngest fan deposits provided results that allow us to constrain the ages of the offset streams incised into the surfaces. We collected and prepared samples following a standard infrared-stimulated luminescence (IRSL) protocol (i.e., Rizza et al., 2011). We used the potassium-feldspar component of the sediment because we anticipated that quartz grains may present dim and unsta- ble signals and therefore would not provide reliable equivalent dose analysis, as we already noticed in another study done in Mongolia (Rizza et al., 2011). Moreover the high dose rates (see Table 2) may have saturated out the quartz component even if the samples were deposited in the past $30 \mathrm{ky}$.

The IRSL samples were analyzed using the fine-grained (4-11 $\mu \mathrm{m})$ fraction and the total-bleach multiple-aliquot additive-dose method (Singhvi et al., 1982; Lang, 1994; Richardson et al., 1997; Aitken, 1998). Fading tests were carried out following the method of Auclair et al. (2003), and the ages were corrected for fading using the functions of Huntley and Lamothe (2001). We collected about $600 \mathrm{~g}$ of material for each sample to measure the concentration of radiogenic thorium $(\mathrm{Th})$, potassium $(\mathrm{K})$, and uranium $(\mathrm{U})$, following Murray et al. (1987). Dose rates were calculated using radioisotope concentration, burial depth, elevation, geomagnetic latitude (Prescott and Hutton, 1994), presentday moisture, and alpha and beta attenuation contributions were corrected for grain-size attenuation. Elemental concentrations and dose rates are shown in Table 2. 
(a)

(b)
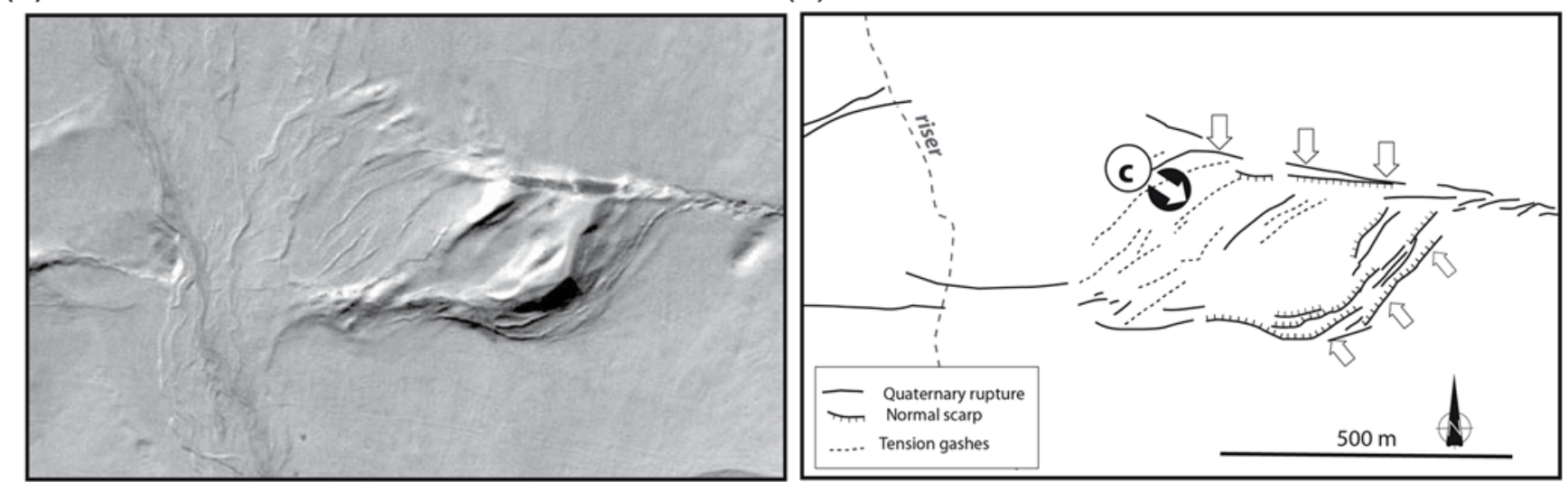

(c)

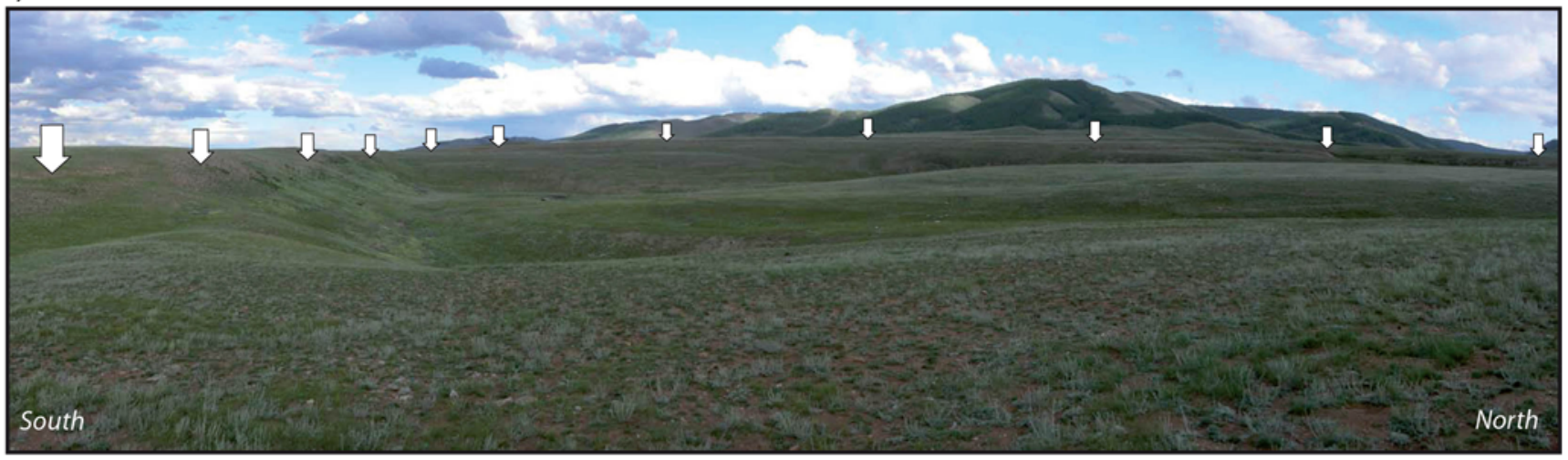

Figure 6. Detailed map of a large pull-apart basin $\left(49.16^{\circ} \mathrm{N}, 97.88^{\circ} \mathrm{E}\right.$ ), east of the Armoise site (location is shown as rectangle D in Fig. 1c). (a) SPOT-5 imagery showing the pull-apart basin. (b) Interpretation of the surface ruptures. In the eastern part of the pull-apart, numerous normal faults are mapped. Label $\mathrm{C}$ shows the location and the arrow indicates the direction from which photo (c) was taken. (c) Field photograph looking west of the graben, the white arrows indicate several of the normal fault scarps active in 1905 . The color version of this figure is available only in the electronic edition.

\section{Genepi Site $\left(98.32^{\circ} \mathrm{E}\right)$}

The Genepi site is located in an area where the Bulnay fault crosses an alluvial plain at the base of the Bulnay range (Figs. 1c and 4). The 1905 surface rupture through this area is expressed as a set of en echelon mole tracks and tension gashes. A stream channel incised into the alluvial surface (S1) is offset, and a small lake occupies a depression formed within an extensional stepover zone along the Bulnay fault (Fig. 8). The stream is blocked by an upstream-facing scarp and flows into the small pond. North of the fault, a small remnant of $\mathrm{S} 1$ is preserved within the incised channel (Fig. 8b). The western riser of this surface marks the edge of an abandoned branch of the stream, whereas the eastern riser marks the edge of the active channel (Fig. 8b). To estimate the cumulative offset, we used the piercing lines corresponding to both sides of the riser between $\mathrm{S} 1$ and the incised channel. Aligning the western and eastern downstream risers with the upstream risers (see Fig. 8c), we found a minimum slip of $\sim 84 \mathrm{~m}$ and a maximum slip of $\sim 107 \mathrm{~m}$, yielding a mean offset of $96 \pm 11 \mathrm{~m}$ (error at $1 \sigma$ ). Reconstructing the geometry

Table 1

Slip Measurements along the Bulnay Fault

\begin{tabular}{lccccc}
\hline \multicolumn{1}{c}{ Site } & Latitude $\left(^{\circ}\right)$ & Longitude $\left(^{\circ}\right)$ & Mean Offset $(\mathrm{m})$ & Uncertainty $(\mathrm{m})$ & Figure ID \\
\hline Lost Goat Creek & 49.1491 & 98.3153 & 9.2 & 0.9 & $7 \mathrm{a}$ \\
Yellow Creek & 49.1805 & 97.3657 & 9.4 & 0.3 & $7 \mathrm{~b}$ \\
Pine Creek & 49.1810 & 97.3615 & 18 & 0.5 & $7 \mathrm{c} / 7 \mathrm{~d}$ \\
Boulder Creek & 49.1832 & 97.3385 & 8.5 & 0.6 & $7 \mathrm{e}(1)$ \\
Boulder Creek & 49.1832 & 97.3385 & 16 & 0.3 & $7 \mathrm{e}(2)$ \\
Horse Creek & 49.1878 & 97.2734 & 8.7 & 0.7 & $7 \mathrm{f}$ \\
Armoise & 49.1579 & 97.8314 & 25 & 4 & $11 \mathrm{a}$ \\
Snow Creek & 49.1884 & 97.2726 & 67 & 17 & $12 \mathrm{~b}$ \\
Genepi & 49.1491 & 98.3255 & 96 & 11 & $8 \mathrm{a}$ \\
\hline
\end{tabular}


(a)

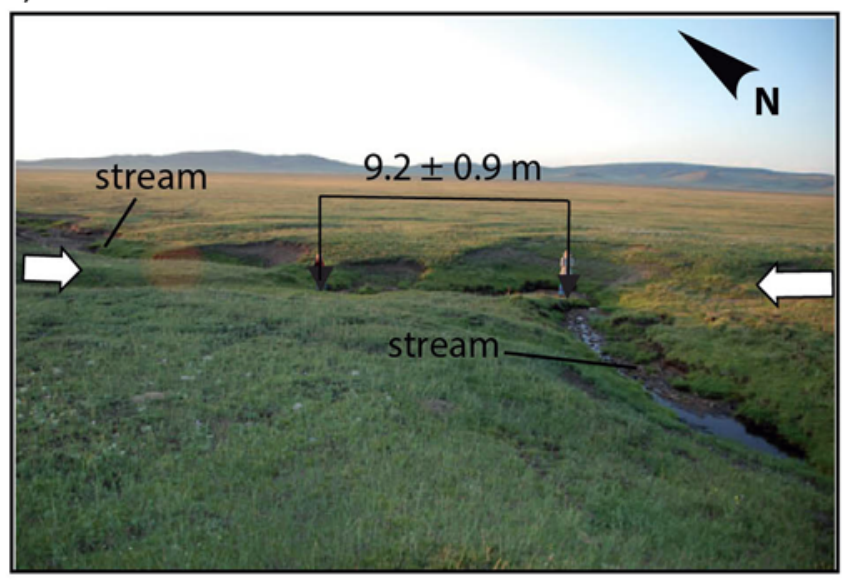

(c)

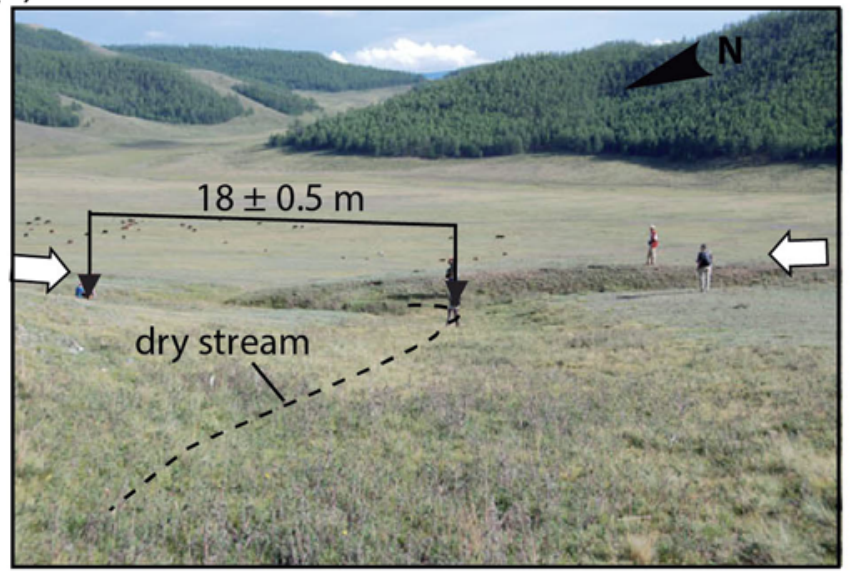

(e)

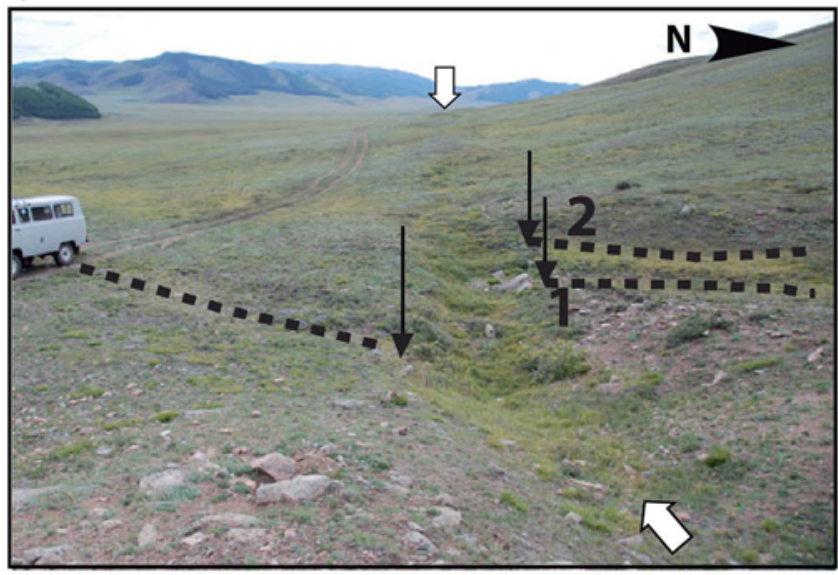

(b)

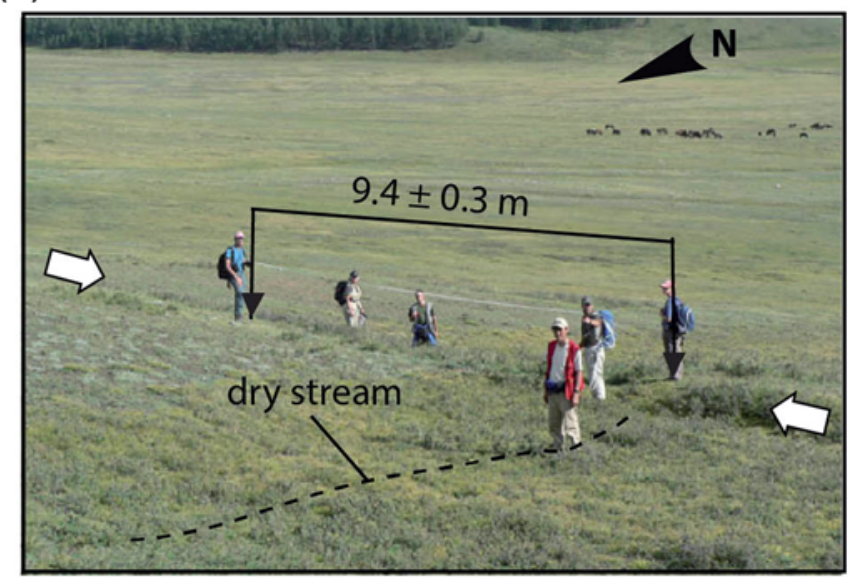

(d)

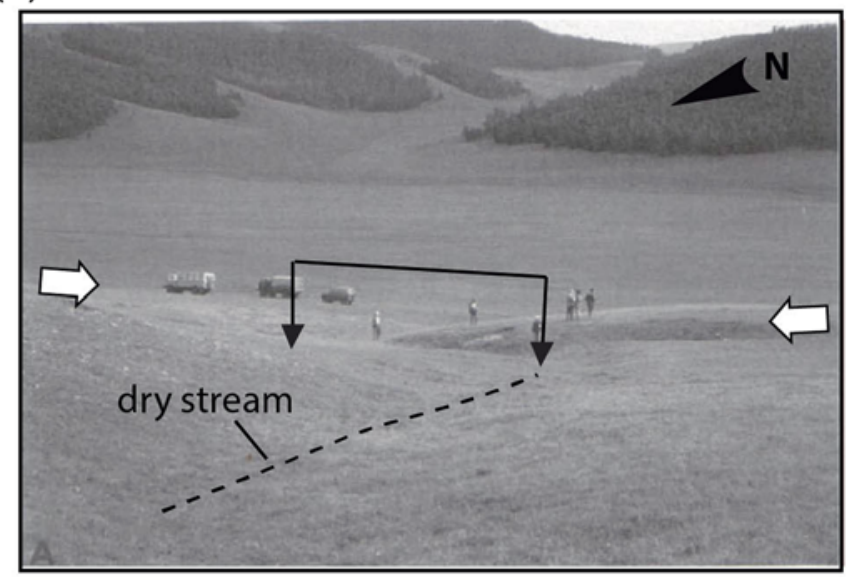

(f)

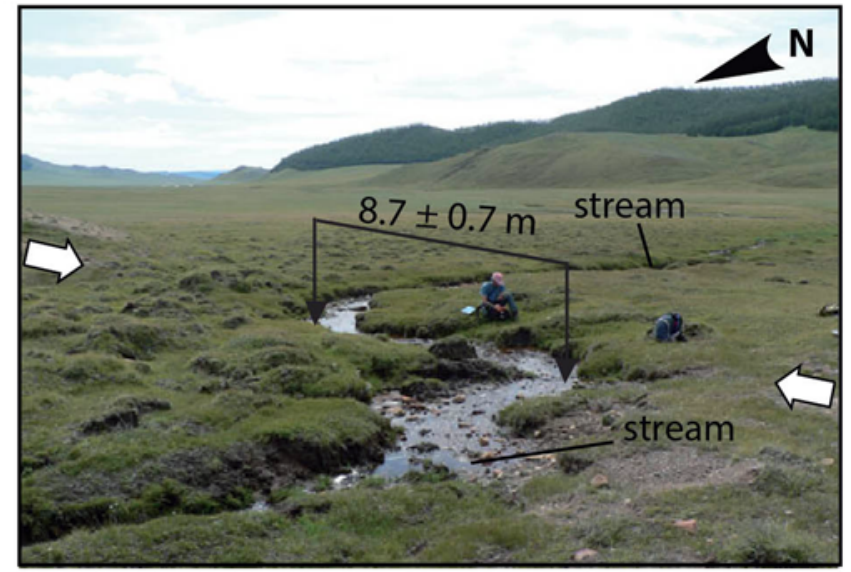

Figure 7. Field photographs of the 1905 and cumulative offsets along the Bulnay fault. (a) 1905 offset at Lost Goat site. The two persons mark the piercing points used to estimate the 1905 coseismic slip. The stream is offset by $9.2 \mathrm{~m}$ across the fault. (b) The 1905 offset at Yellow Creek site. The dry stream channel is offset by $9.4 \mathrm{~m}$. (c) The cumulative offset at Pine Creek site. The dry stream is offset by $18 \mathrm{~m}$. (d) Field photograph taken in 1992 by Baljinnyam et al. (1993) of the same site. (e) View west of the Boulder Creek site, where we define the 1905 offset using piercing line 1 , which is the active channel north of the fault, and a cumulative offset using piercing line 2 , which is an abandoned channel north of the fault, with respect to the active stream channel south of the fault (black dashed lines). The offsets are $8.5 \mathrm{~m}$ and $16 \mathrm{~m}$, respectively. (f) The 1905 stream offset at Horse Creek site is $8.7 \mathrm{~m}$. The color version of this figure is available only in the electronic edition.

of the stream with the $96 \mathrm{~m}$ offset yields the best fit for the initial geometry of the incision. When reconstructing this offset, a remnant $\mathrm{S} 1$ surface stands in the middle of the downstream channel, suggesting that the initial incision was narrower and that the channel has broadened eastward overtime. 


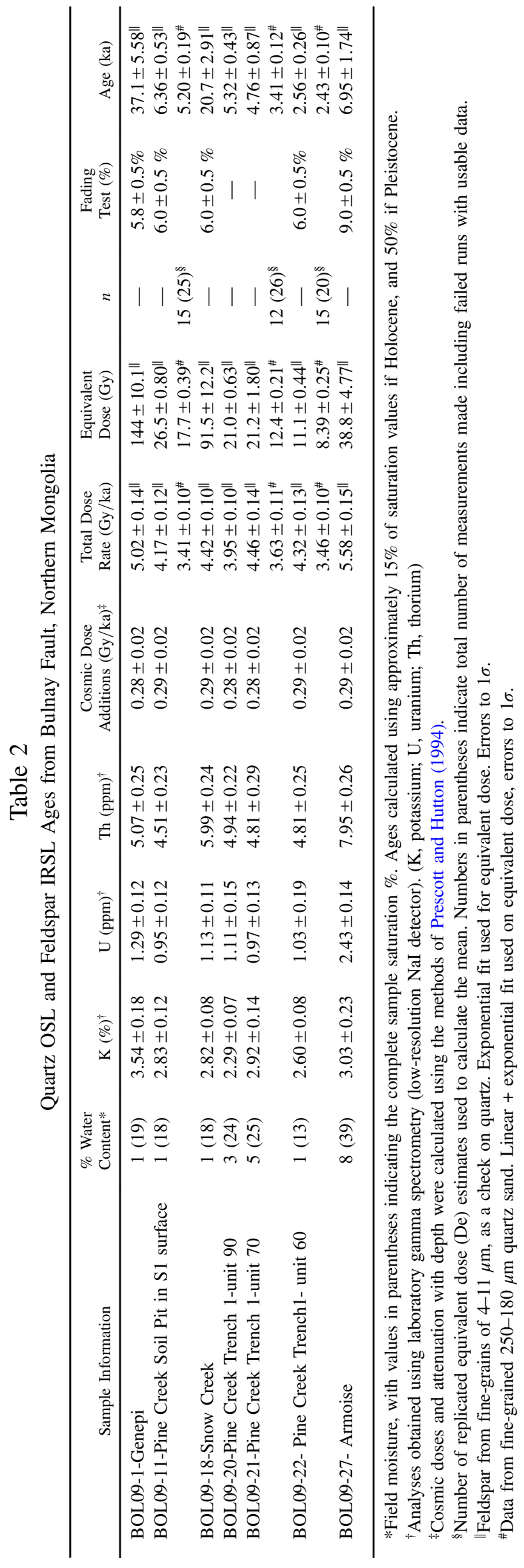

We determined the age of surface S1 using IRSL to date the uppermost depositional unit. Sample BOL09-OSL1 was collected at $50 \mathrm{~cm}$ depth within unit 1 (Fig. 9a), and yielded an age of $37.1 \pm 5.6 \mathrm{ka}$ after applying a fading correction of $5.8 \pm 0.5 \%$, following Auclair et al. (2003) and Huntley and Lamothe (2001) (see Table 2). The distribution of the ${ }^{10} \mathrm{Be}$ concentration within unit 1 cannot be modeled without making strong assumptions, and we therefore do not infer any ages (ㅌ) see Fig. S2).

Because we do not know when the channel incision occurred with respect to the seismic cycle (i.e., just before or just after an earthquake, or sometime in between; Fig. 10), we calculated the slip rate along the fault considering that the cumulative offset is bracketed between the total cumulative offset $(96 \pm 11 \mathrm{~m})$ and the total cumulative offset minus the 1905 offset measured at Lost Goat Creek $(87 \pm 12 \mathrm{~m})$, assuming a periodic behavior. This yields a cumulative offset range of 75-107 m. Dividing this offset by the IRSL age of the surface $(37.1 \pm 5.6 \mathrm{ka})$, which provides a maximum bound on the timing of stream incision, yields a minimum slip rate of $2.6 \pm 0.8 \mathrm{~mm} / \mathrm{yr}$.

\section{Armoise Site $\left(97.85^{\circ} \mathrm{E}\right)$}

The Armoise Creek site is located $\sim 35 \mathrm{~km}$ west of the Genepi site, where the 1905 surface rupture is a single fault trace that crosses two terraces ( $\mathrm{S} 1$ and $\mathrm{S} 0$ ) incised by an active stream (Fig. 11). On the east side of the stream, the riser between $\mathrm{S} 1$ and $\mathrm{S} 0$ is well preserved and is left-laterally displaced. Using the same methodology as at Genepi, we made a detailed topographic map of the site using Real Time Kinematic (RTK) GPS surveying and used the piercing lines corresponding to the tops of the risers on both sides of the stream to estimate the offset. Reconstructing the western and eastern risers, we found offsets of $17 \pm 5 \mathrm{~m}$ and $25 \pm 4 \mathrm{~m}$, respectively. The difference between the two offset risers suggests that the western riser has experienced more erosion from the stream channel and is therefore a minimum cumulative offset. Restoring $\sim 23 \mathrm{~m}$ of slip produced the best fit for the initial geometry of the incision and also shows that the shape of the stream channel was probably curved before the record of successive left-lateral displacements.

We determined the age of surface S1 using IRSL to date sample BOL09-OSL27, which was collected at a depth of $45 \mathrm{~cm}$, near the top of unit 2 immediately below the A horizon that forms the ground surface (Fig. 9b). The IRSL analysis yielded an age of $6.9 \pm 1.7 \mathrm{ka}$ after applying a fading correction of $9.0 \pm 0.5 \%$, following Auclair et al. (2003) and Huntley and Lamothe (2001) (Table 2). The ${ }^{10} \mathrm{Be}$ concentrations (E) see Fig. S3) are similar at the top and bottom of the profile, suggesting samples contain mostly inherited ${ }^{10} \mathrm{Be}$ and therefore that the surface was recently abandoned. Indeed an exposure time of $7000 \mathrm{yrs}$ would correspond to a fraction of ${ }^{10} \mathrm{Be}$ concentration ranging from $1 \%$ (BOL09-32) to $14 \%$ (BOL09-26B) of the measured concentrations that is within the measured analytical uncertainties (E) see Table S1). This 
(a)

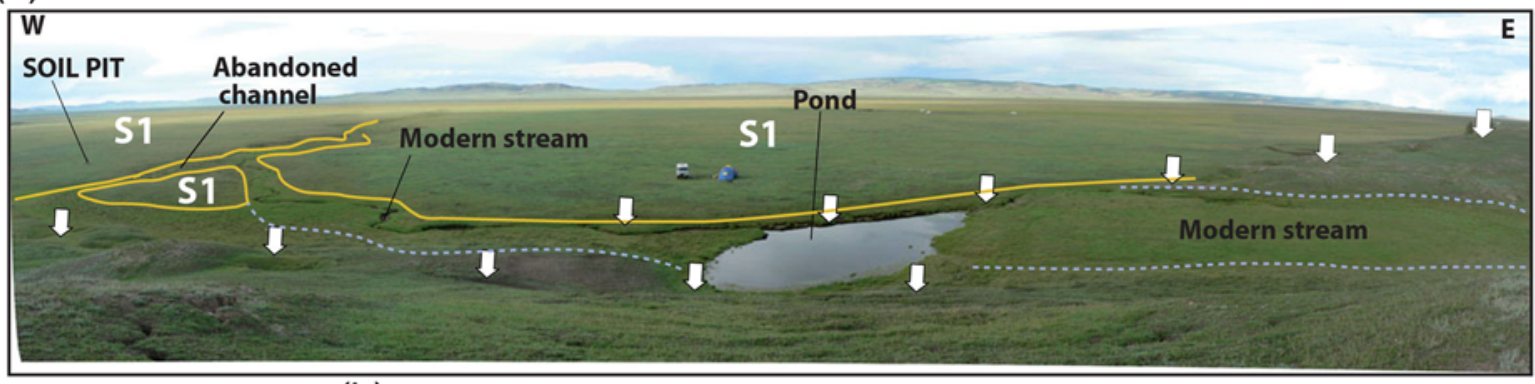

(b)

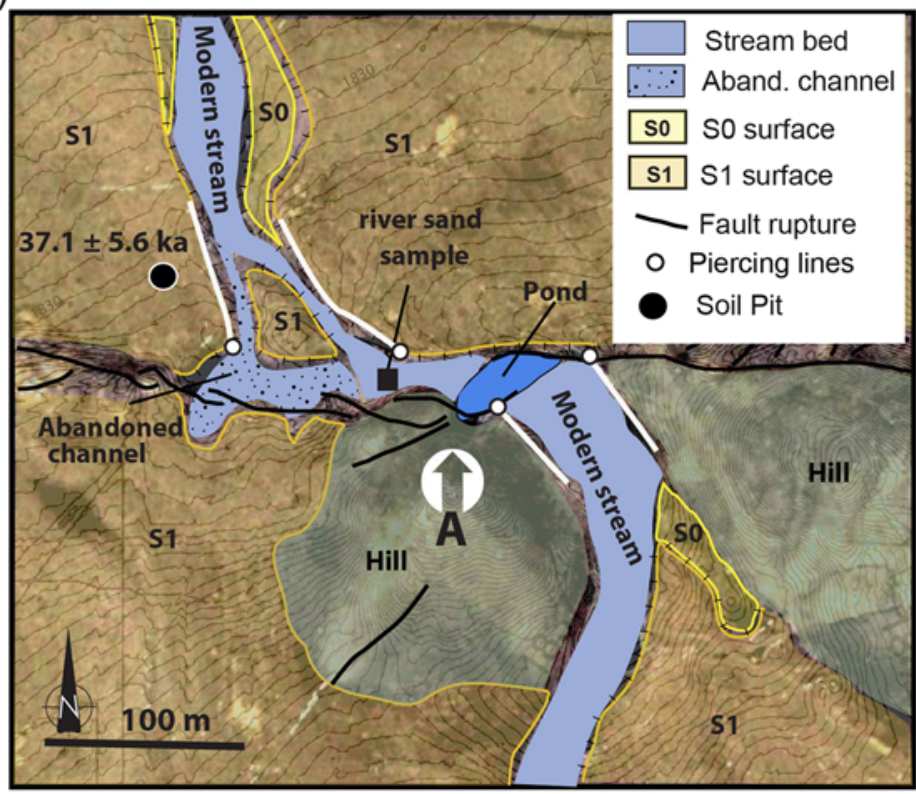

(c)

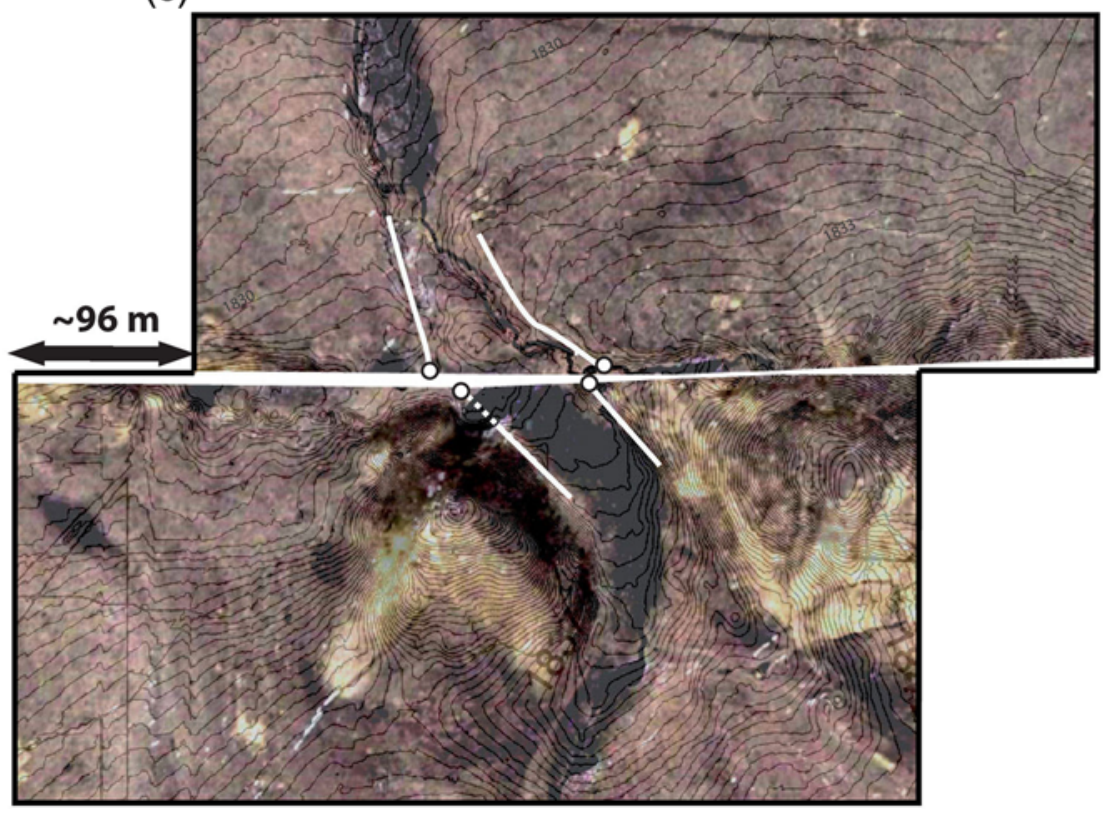

Figure 8. Genepi site. (a) Panorama looking south, giving an overview of the Genepi area. White arrows mark the fault zone. (b) Google Earth imagery (see Data and Resources) combined with our DEM and interpretations. The lines on both sides of the channel show the top of the risers of the stream channel that we used as piercing lines (dots). Modern stream channels on both sides of the fault zone are represented, and we mapped the pond developed in the fault stepover area. We also mapped an abandoned channel; the dark solid lines are fault traces. The contour interval is $0.25 \mathrm{~m}$. Arrow A shows the viewpoint and view direction of the photograph in (a). (c) Reconstruction of the initial position of the channel defining a cumulative displacement of $\sim 96 \mathrm{~m}$. The color version of this figure is available only in the electronic edition. 
(a)
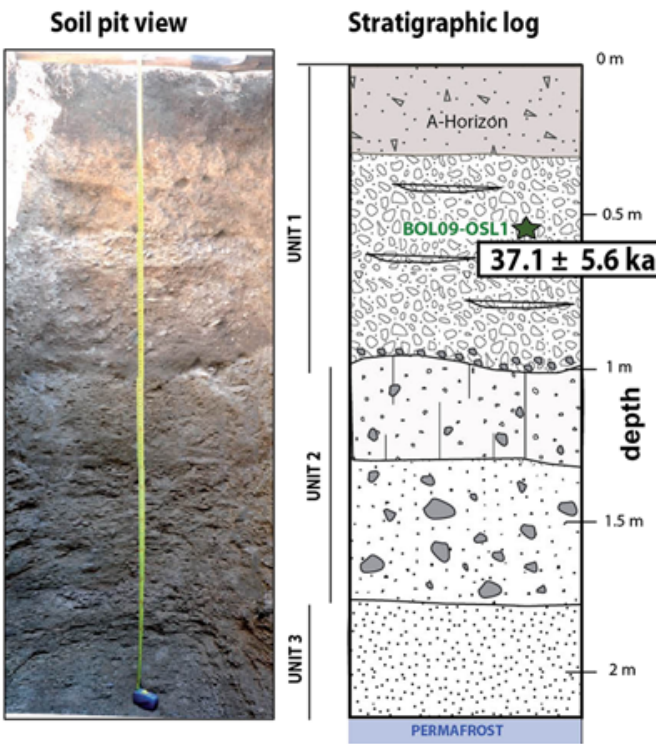

(c)

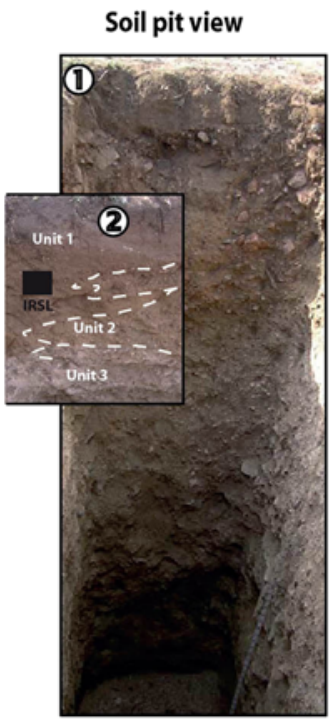

(b)

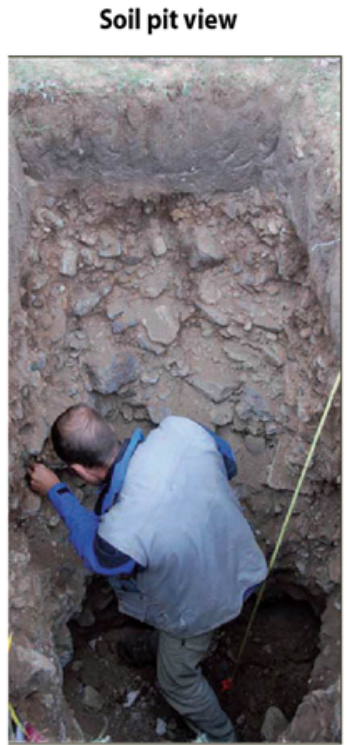

ARMOISE CREEK

Stratigraphic log

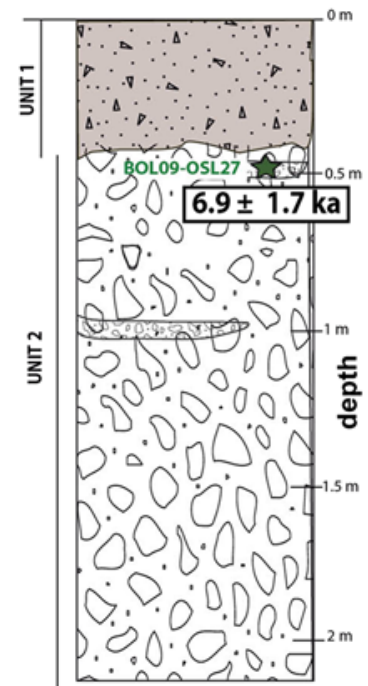

(d)

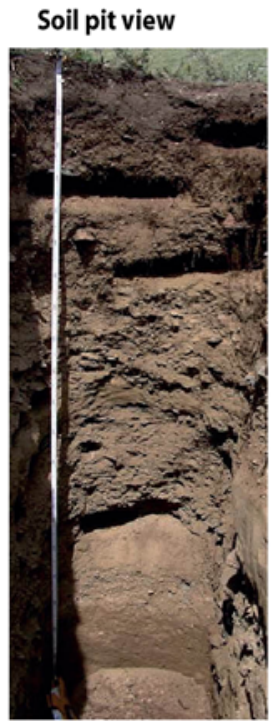

Stratigraphic log

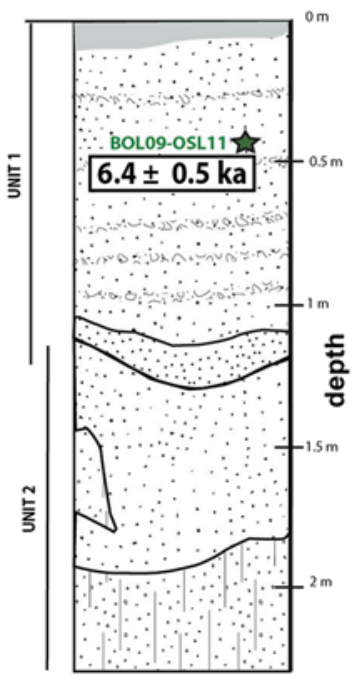

Figure 9. Soil pit stratigraphy and luminescence analyses at four sites. (a) The Genepi site (see location in Fig. 8). Field photograph of the soil pit and corresponding stratigraphic log of the profile and location of the infrared-stimulated luminescence (IRSL) sample (star). The soil pit exposed organic-rich soil (30 $\mathrm{cm}$ wide) with organic materials and roots located at the top of unit 1, which is composed of pebbles in organic-rich sandy matrix. At $\sim 100 \mathrm{~cm}$ depth, we observed a layer of rounded pebbles suggesting that the base of unit 1 eroded into unit 2 . Unit 2, between 100 and $180 \mathrm{~cm}$ depth, is composed of cobbles in a coarse sandy matrix near its base and grades upward to pebbles in a sandy-clay matrix. Unit 3, between 180 and $210 \mathrm{~cm}$, is composed of coarse sand with rare pebbles. At the base of this unit, we encountered permafrost at a depth of $2.2 \mathrm{~m}$. (b) Soil pit stratigraphy and luminescence analyses at the Armoise site (see location in Fig. 11). Field photograph of the soil pit and corresponding stratigraphic log of the profile and location of the IRSL sample (star). Unit 1 is organic-rich soil horizon with organic materials with a thickness of $\sim 30 \mathrm{~cm}$. Unit 2 is a massive debris flow containing subangular quartzite pebbles (5$15 \mathrm{~cm}$ in diameter) in a coarse sandy matrix. (c) Soil pit stratigraphy and luminescence analyses at the Snow Creek site (see location in Fig. 12). Field photographs of the soil pit: (1) view of alluvial deposits within the profile and (2) detailed view of the profile wall where the luminescence sample was collected. The IRSL sample was collected within unit 1 at $45 \mathrm{~cm}$ depth. Stratigraphic log, showing the locations of the IRSL sample (star). Organic-rich soil (unit 1) containing organic materials and roots is located at the top of unit 2, which consists of poorly stratified pebbles in a fine sandy matrix. Unit 3, from $\sim 60$ to $\sim 180 \mathrm{~cm}$, is a bed comprised of cobbles in a coarse sandy matrix at the base to small pebbles $(<4 \mathrm{~cm})$ in a sandy matrix near the top. Unit 4, from $\sim 180$ to $\sim 230 \mathrm{~cm}$, is comprised of coarse sands with rare pebbles. (d) Soil pit stratigraphy and results of luminescence analyses of samples collected in the S1 soil pit at Pine Creek (see location in Fig. 13). Field photograph showing the alluvial deposits exposed in the soil pit and stratigraphic log and locations of the IRSL sample (star). The color version of this figure is available only in the electronic edition. 


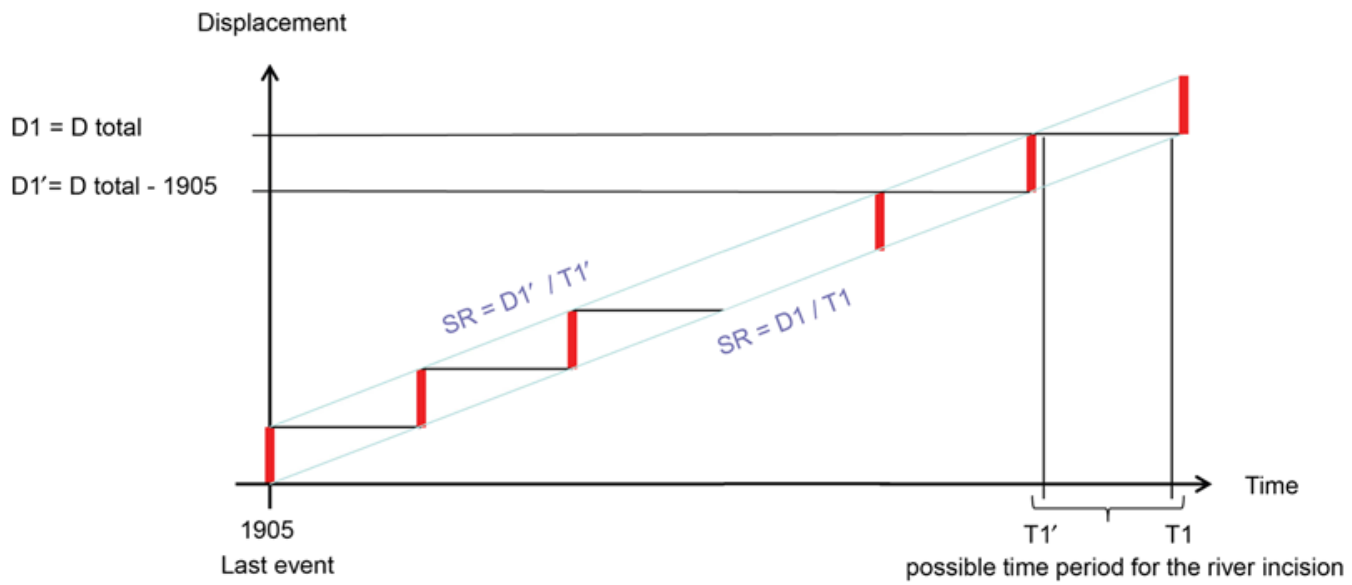

Figure 10. The relationships between the cumulative displacements of a morphological marker (a stream incising surface S1), its age of formation (age of abandonment of surface S1 or age of the last deposits on surface S1) during the seismic cycle, and the estimated slip rate along a strike-slip fault, assuming a characteristic slip behavior. Note that, contrary to the reverse fault setting, where we know that the age of the abandonment of the surface immediately postdates an event (e.g., Ritz et al., 2003), in the case of strike-slip faults, we do not know when the marker (i.e., surface) forms with respect to the occurrence of seismic events. The color version of this figure is available only in the electronic edition.

cannot be clearly determined using the depth profile modeling, but the ${ }^{10} \mathrm{Be}$ data validate the recent deposition of S1 surface, as shown by the OSL age.

To estimate the slip rate, we followed the same protocol employed at the Genepi site. Because we do not know when the channel incision occurred with respect to the seismic cycle (see Fig. 10) and we are unable to estimate the amount of erosion on the western riser since the deposition of $\mathrm{S} 1$, we give preference to our slip estimate of the well-preserved eastern riser. We then bracketed the cumulative offset between $25 \pm 4 \mathrm{~m}$ and the total cumulative offset minus the 1905 offset $(16.1 \pm 4.5 \mathrm{~m})$. (We used the mean 1905 value calculated from all the sites because we do not have a measurement of 1905 slip near Armoise Creek.) This conservative approach yields a cumulative offset ranging between 12 and $29 \mathrm{~m}$; dividing this offset by the IRSL age $(6.9 \pm 1.7 \mathrm{ka})$, we estimate a slip rate of $3.5 \pm 2 \mathrm{~mm} / \mathrm{yr}$, indistinguishable within the error from the rate determined at the Genepi site.

\section{Snow Creek site $\left(97.27^{\circ} \mathrm{E}\right)$}

The Snow Creek site is located $\sim 37 \mathrm{~km}$ west of the Armoise Creek site, where the Bulnay fault crosses an alluvial surface and is expressed as a series of mole tracks and tension gashes (Fig. 12a). Based on our interpretation of aerial photographs (1:25,000 scale, 1973, photographs of Bulnay fault are courtesy of D. Schwartz), we identified a left-laterally offset stream incised into the alluvial surface (S1). The riser between $\mathrm{S} 1$ and the incised stream forms a piercing line that is highlighted by snow cover on the east-facing slope of the channel in the aerial photography (Fig. 12b). The initial position of the upstream channel in the topography is not clear in this flat morphology. We then project the piercing lines from a distance of $\sim 30-40 \mathrm{~m}$ along the fault zone to estimate the cumulative slip (Fig. 12b). The downstream channel is narrower, and we defined the piercing lines using both sides of the channel incision. Reconstruction of the initial position of the channel yields offsets of $74 \pm 10 \mathrm{~m}$ and $57 \pm 7 \mathrm{~m}$ for the western and eastern risers, respectively (Fig. 12c).

We determined the age of the most recent deposits at the top of surface S1 using IRSL to date sample BOL09-OSL18, collected at a depth of $40 \mathrm{~cm}$ from a fine-grained sandy unit (Fig. 9c). The IRSL analysis yielded an age of $20.7 \pm 2.9 \mathrm{ka}$ after applying a fading correction of $6 \pm 0.5 \%$ (see Table 2). Using ${ }^{10} \mathrm{Be}$ concentrations, we estimate an age of $45.7 \pm 3.8 \mathrm{ka}$ for the same unit that we consider as a maximum age of deposition, because we are not taking inheritance into account and this age is only based on a single pebble (E) see Fig. S4). Our OSL age is much younger, but it is not inconsistent if the measured ${ }^{10} \mathrm{Be}$ concentration of the sample contains inheritance (E) as observed within unit 2 in the same profile; see Fig. S4).

To be conservative and because we have large uncertainties for the initial position of the channel incision, we estimate the cumulative offset to be between 50 and $84 \mathrm{~m}$. As for Genepi and Armoise sites, we estimated the slip rate at Snow Creek using an offset range that combines the total cumulative offset (50-84 m) and the total cumulative offset minus the 1905 offset measured at nearby Horse Creek (41-75 $\mathrm{m}$ ). Dividing these offset ranges $(41-84 \mathrm{~m})$ by the IRSL age $(20.7 \pm 2.9 \mathrm{ka})$ yields a maximum slip rate of $3.2 \pm 1.5 \mathrm{~mm} / \mathrm{yr}$.

\section{Paleoseismic Investigations at Pine Creek $\left(97.36^{\circ} \mathrm{E}\right)$}

The Pine Creek site $\left(97.36^{\circ} \mathrm{E}\right)$ is about $30 \mathrm{~km}$ west of the Armoise site and about $7 \mathrm{~km}$ east of the Snow Creek site, where the Bulnay fault traverses a mountainous area (Fig. 1). At this site the fault cuts across an alluvial fan deposit near the outlet of a small catchment incised into the massif. This 
(a)

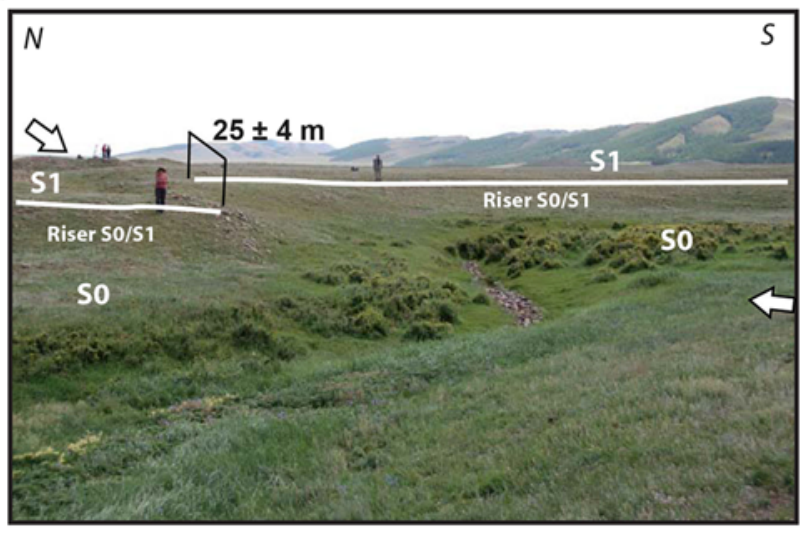

(c)

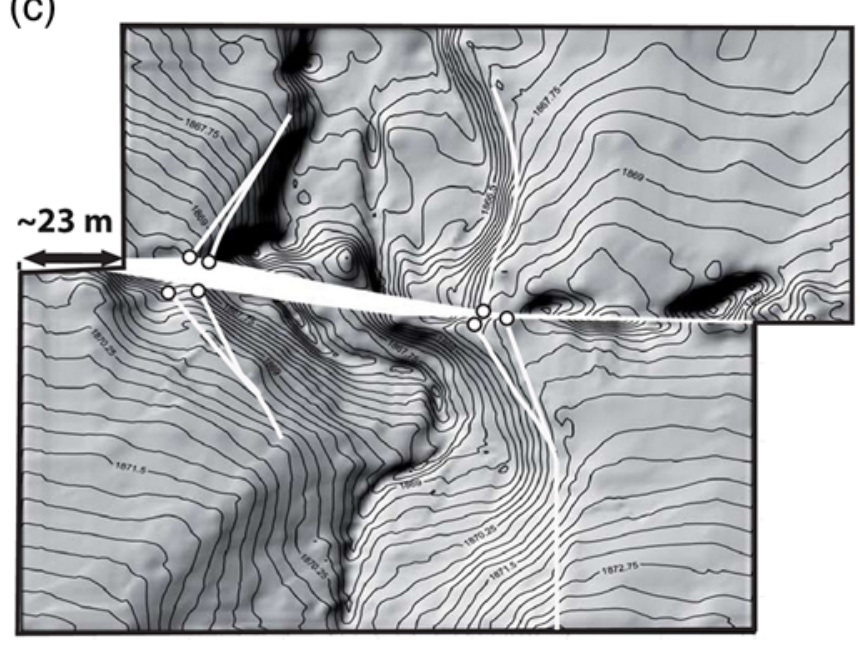

(b)

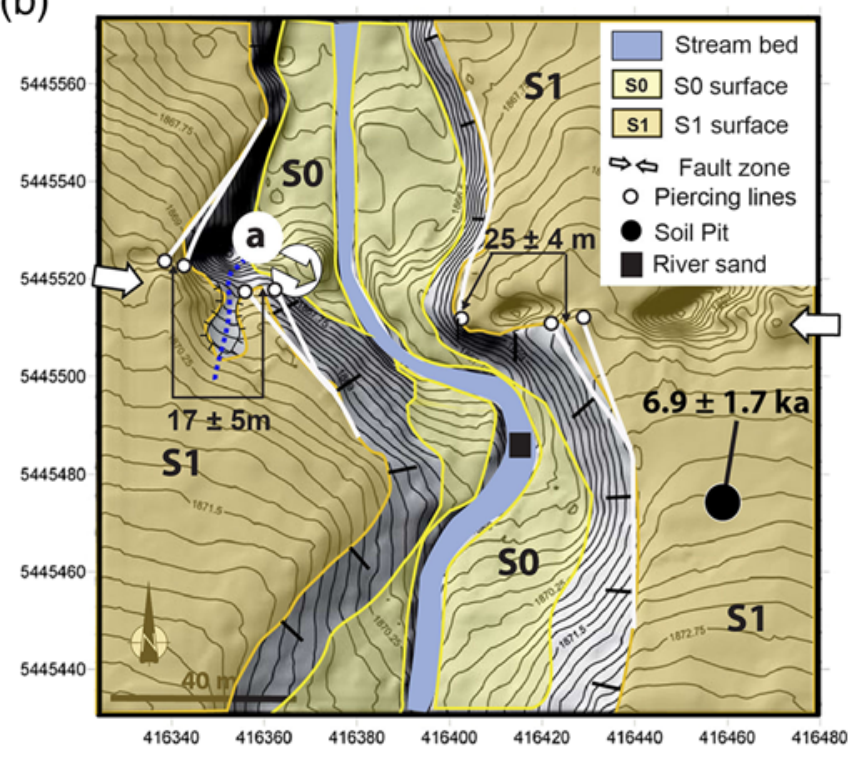

Figure 11. Armoise site. (a) Field photograph looking east at Armoise Creek, incised into alluvial surface S1. The solid lines mark the top of the riser between stream terrace S0 and S1 on the east side of the stream, which is offset across the Bulnay fault. We used this riser and the corresponding riser on the west side of the stream as piercing lines to measure postincision offsets. (b) DEM of the study area showing the Armoise Creek site, our interpretations, and the offset terrace risers (solid lines and dots) used to measure the cumulative offset. The contour interval is $25 \mathrm{~cm}$. White arrows indicate the Bulnay fault. Arrow a shows the viewpoint and view direction of the photograph in (a). The axes show UTM grid northing and easting values in meters. (c) Reconstruction of $\sim 23 \mathrm{~m}$ of slip across the Bulnay fault. This represents our preferred estimate of the total slip across the Bulnay fault post incision of Armoise Creek into S1. The color version of this figure is available only in the electronic edition.

alluvial fan surface (S1) has been incised by a stream channel that is left-laterally offset across the fault. We mapped this area in detail using kinematic GPS; and, by aligning the downstream risers with the upstream risers of the fan surface, we estimate the stream offset to be $18.0 \pm 0.5 \mathrm{~m}$ to produce the best fit for the initial geometry of the channel incision (Fig. 13). Because the nearby Yellow Creek drainage is offset by $9.4 \pm 0.3 \mathrm{~m}$ (Fig. 7b), we interpret the offset stream at Pine Creek to be the result of two earthquakes. To develop a chronology for the pre1905 rupture history and to investigate the recurrence times of large earthquakes along the Bulnay fault, we undertook a paleoseismological investigation at this location.

We opened a $3 \mathrm{~m}$ long, hand-dug trench across the fault zone within the displaced stream channel (Fig. 13). We logged the trench walls at a scale of $1: 10$ using a $0.5 \mathrm{~m}$ grid spacing (Figs. 14 and 15). The trench exposed stratified alluvial deposits below the S1 fan surface (units 110-120) and younger channel deposits incised into S1 (units 60-90), all of which are offset (see stratigraphic descriptions in Table 3). The fault zone is about $1.5 \mathrm{~m}$ wide and is made up of several distinct faults labeled Z1-Z5. The logs of the two walls of trench 1 show evidence for three events since the deposition of the alluvial surface: two of them, including the 1905 surface rupture, occurred after the incision of the alluvial fan surface, and one of them occurred during the late stages of fan accumulation, prior to incision. We collected samples for luminescence and radiocarbon dating to bracket the ages of the prehistoric ruptures, and we also excavated a soil pit near the fault zone to collect luminescence and ${ }^{10} \mathrm{Be}$ samples to date the age of the S1 surface (Table 2 and (E) Fig. S5).

\section{Evidence for the 1905 Earthquake}

The 1905 earthquake is well expressed in the western wall below unit 10 , which is undeformed and therefore 
(a)

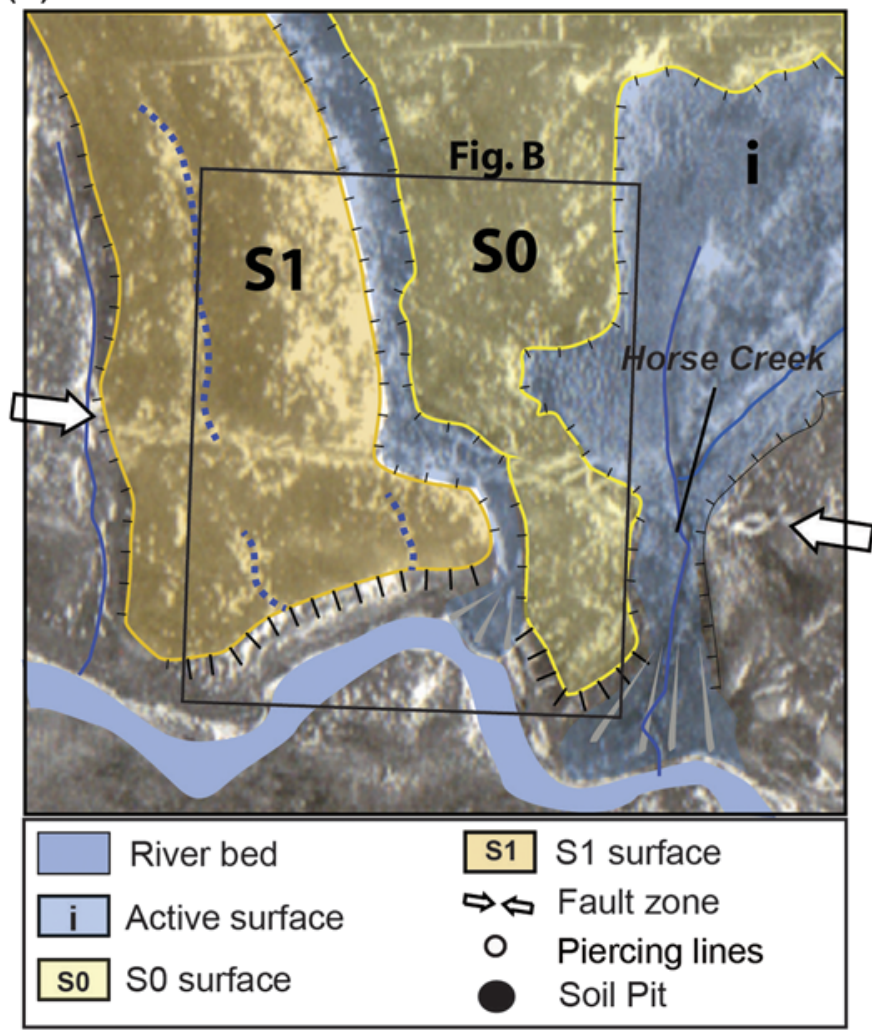

(b)

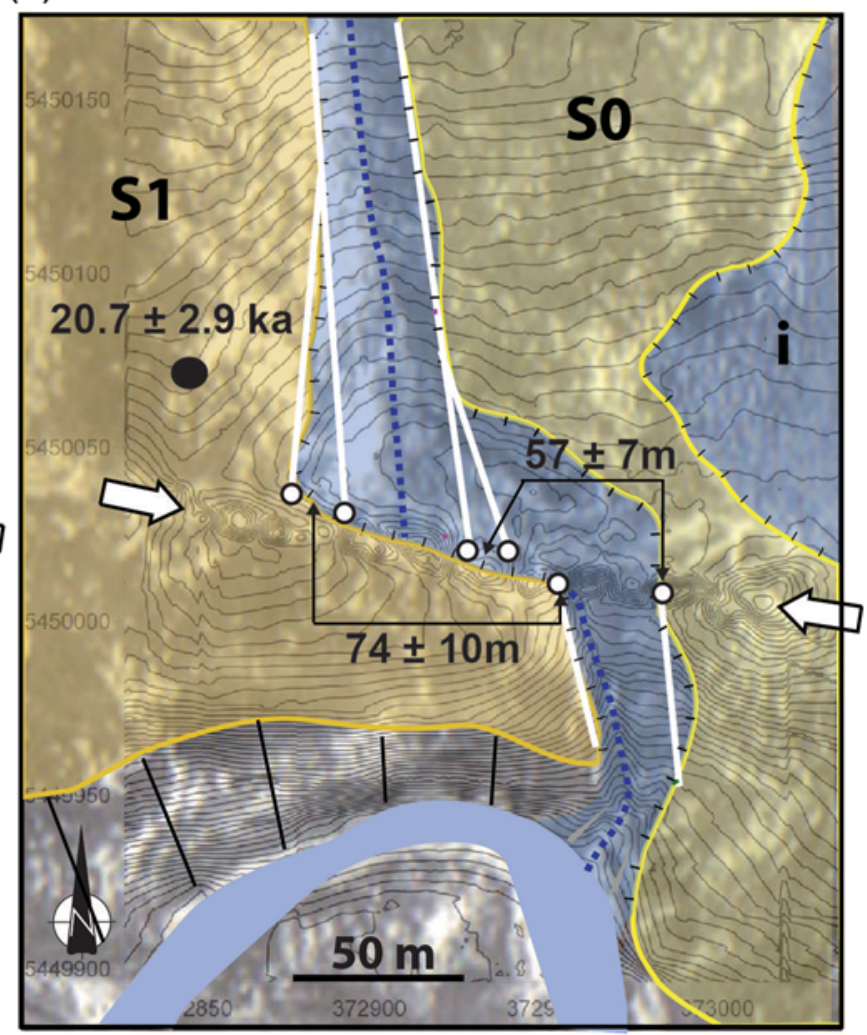

Figure 12. Snow Creek site. (a) Aerial photograph with snow highlighting riser between the S1 and the S0 surfaces. Our morphological interpretations are draped on the aerial photograph. The white arrows indicate the Bulnay fault. (b) Aerial photograph combined with the DEM and our morphological interpretations, showing the piercing lines used to measure the cumulative displacement of the S1/S0 riser (solid lines and dots). The contour interval is $0.5 \mathrm{~m}$. The white arrows indicate Bulnay fault. Numbers on the $y$ and $x$ axes are UTM grid northing and easting values in meters. The color version of this figure is available only in the electronic edition.

was deposited after the 1905 event (Fig. 14). Near the southern end of the trench, the Z1 shear zone breaks all units older than unit 10 and is associated with a fissure $\left(f_{1}\right)$ that is filled with chaotic, unsorted materials composed of pebbly, silty sand (Fig. 14). We also identified the upward termination of fault $Z 1$ below unit 10 on the eastern wall (Fig. 15). The Z1 fault zone juxtaposes different units due to left-lateral slip during the 1905 earthquake. Another fissure $\left(f_{2}\right)$ associated with the 1905 earthquake is exposed near the northern end of the western wall and is filled with colluvium that includes fragments of the organic-rich unit 20, which we interpret to represent a horizon just below the ground surface in 1905. In the opposite wall, a fissure is exposed near the northern end of the trench $\left(\mathrm{f}_{2}^{\prime}\right)$ that also contains fragments of unit 20.

\section{Evidence for the Penultimate Earthquake (Event 2)}

The penultimate earthquake is well expressed on both walls of the exposure (Figs. 14 and 15). Faults Z2 and Z3 break the fan deposits (units 110-120) and overlying unit 70 but do not break unit 65 or younger units. The upward terminations of faults Z2 and Z3 are overlain by coarse, sandy channel deposits associated with the offset stream (units 65 and 60; Figs. 14 and 15). These deposits filled the small graben created between faults $\mathrm{Z} 2$ and $\mathrm{Z3}$ during the penultimate earthquake and overlie the former ground surface, labeled "g" (Fig. 15). Additional evidence for the penultimate event is found within the eastern wall at the top of the $\mathrm{Z} 4$ fault, where a fissure $\left(\mathrm{f}_{3}^{\prime}\right)$ that is filled with unsorted loose sediment is overlain by a remnant piece of unit 20 , which was at the ground surface during the 1905 earthquake. We interpret this feature as a fissure formed during the penultimate earthquake.

These observations show that the penultimate earthquake occurred after fan incision because the penultimate fault traces (Z2 and Z3) disrupt the channel deposits (unit 70) associated with the stream that is incised into the fan deposits. After the penultimate earthquake, renewed incision and filling occurred, associated with the younger coarse stream deposits of units 65 and 60. This channel was subsequently faulted during the 1905 event along the Z1 fault.

\section{Evidence for the Third Event (Event 3)}

We found evidence for a third earthquake near the north end of the trench, where we identified upward terminations of fault zones Z4 and Z5 in both walls (Figs. 14 and 15). In 
(a)

(b)
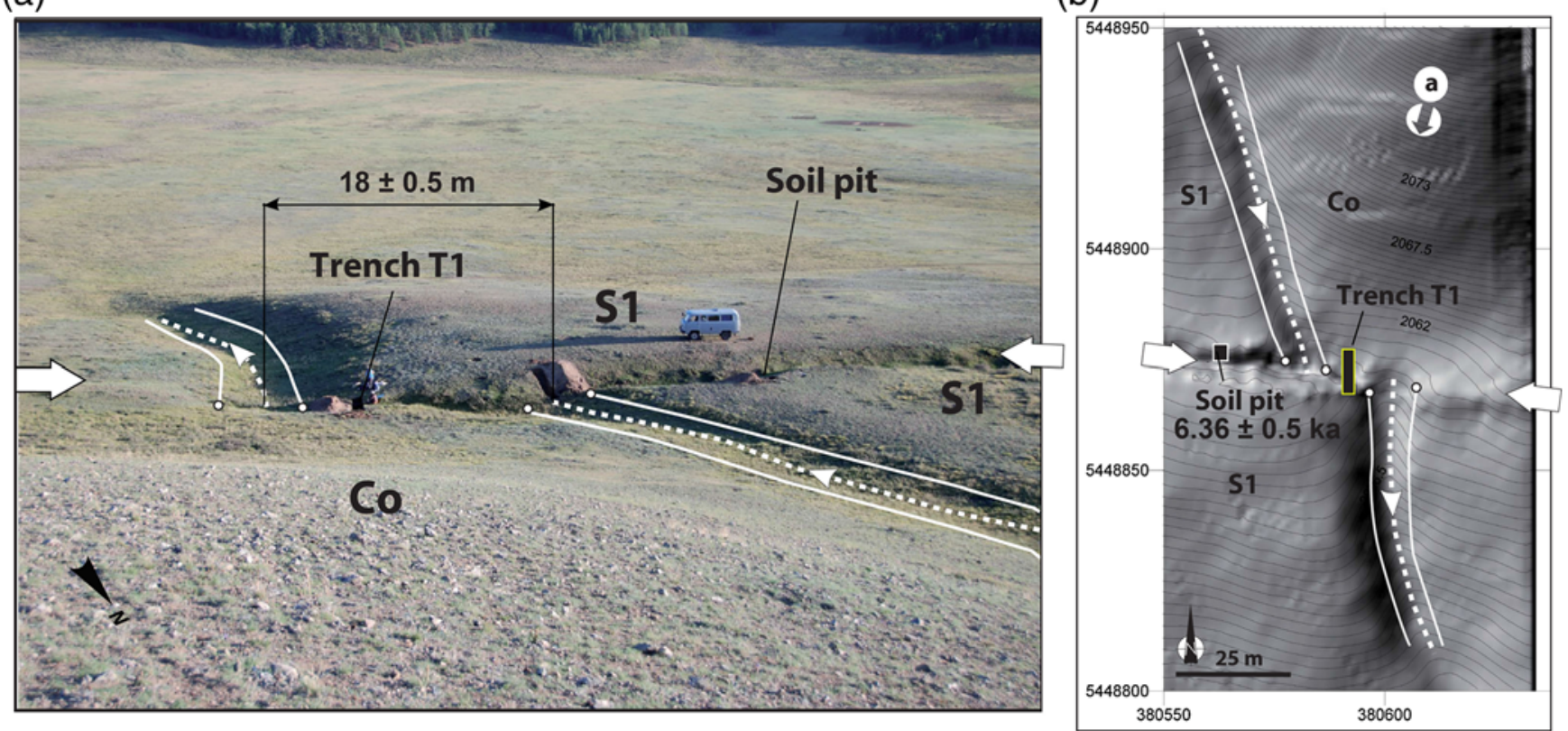

Figure 13. (a) Field view of the Pine Creek site looking south, showing the locations of trench $\mathrm{T} 1$ and the soil pit excavated into the S1 alluvial surface. Co indicates the slope colluvium deposits. The white dashed lines mark the left-laterally offset channel, and the solid lines and their associated dots on both sides of the stream bed are used to measure postincision fault slip. White arrows indicate Bulnay fault. (b) DEM of the study area and the piercing lines and dots used to measure the offset $(\sim 18 \mathrm{~m})$. Contour interval is $0.5 \mathrm{~m}$. The white arrows indicate the Bulnay fault and arrow a shows the viewpoint and view direction of the photograph shown in (a). Numbers on the $y$ and $x$ axes are UTM grid northing and easting values in meters. The color version of this figure is available only in the electronic edition.

the western wall, these two faults break the alluvial fan deposits (unit 110) but do not offset unit 90, the oldest postfan stream deposits (Fig. 14). The third event is also well expressed near the north end of the eastern trench wall where upward fault terminations and filled fissures are exposed beneath the stream deposits of unit 90 (Fig. 15). These relationships show that the third event occurred during the late stages of alluvial fan deposition and before the deposition of unit 90, which represents the beginning of stream incision into the alluvial fan surface (S1). The incised stream was subsequently offset twice, during the penultimate and the 1905 earthquakes, consistent with our interpretation of the morphology of the offset stream.

\section{Age Control}

We collected luminescence samples from the western wall of T1, within the sandy matrix of unit 60 (BOL09-22) and within the coarse matrix of unit 70 (BOL09-21), to constrain the timing of the penultimate earthquake (Fig. 15). Polymineral analyses of these samples provide ages that bracket the penultimate earthquake between $2560 \pm 260 \mathrm{yr}$ and $4760 \pm 870 \mathrm{yr}(1 \sigma$, Table 2$)$. We also collected two bulk samples for radiocarbon dating that predate the penultimate event, one from paleosol G (PC-T1-4) and one from unit 80 (PC-T1-6) (Table 4). These yield 2- $\sigma$ age ranges of 3580$3720 \mathrm{cal}$ B.P. and 3060-3240 cal B.P., respectively. We also collected charcoal samples for radiocarbon dating from the eastern wall, within unit 60 (PC-T1-7) and within the organic-rich unit $g$ (PC-T1-2). Radiocarbon dating yielded $2-\sigma$ age ranges of $4650-4870 \mathrm{cal}$ B.P. and $4350-4450 \mathrm{cal}$ B.P. for PC-T1-7 and PC-T1-2, respectively. These two radiocarbon samples are not in stratigraphic order and suggest that charcoal sample PC-T1-7 from unit 60 is detrital. Luminescence sample BOL09-22 gives a younger age for unit 60, providing further evidence that the charcoal sample from that unit is inherited. We therefore use the ages of luminescence sample BOL09-22 and radiocarbon sample PC-T1-6 to bracket the age of the penultimate earthquake between 2300 and 3240 cal B.P. This age is consistent with the ages of luminescence sample BOL09-21 and radiocarbon samples PC-T1-4 and PC-T1-2.

To postdate the third event we collected luminescence sample BOL09-20 from the western wall within the sandy matrix of unit 90 , which yielded an age of $5320 \pm 430 \mathrm{yr}$. We also collected radiocarbon sample PC-T1-1 from the eastern wall, from a fissure fill created at the time of the third event associated with the $\mathrm{Z} 5$ fault within the alluvial fan deposits (unit 110). The material within the fissure is comprised of inherited sediments derived from unit 110 at the time of the third event and therefore predates the earthquake. Radiocarbon dating yielded a $2-\sigma$ age range of 8540 $8770 \mathrm{cal}$ B.P. and provides a maximum age constraint for the third earthquake. The third event occurred between $4890 \mathrm{yr}$ and 8770 cal B.P., bracketed by BOL09-20 and PC-T1-1. 
(a)

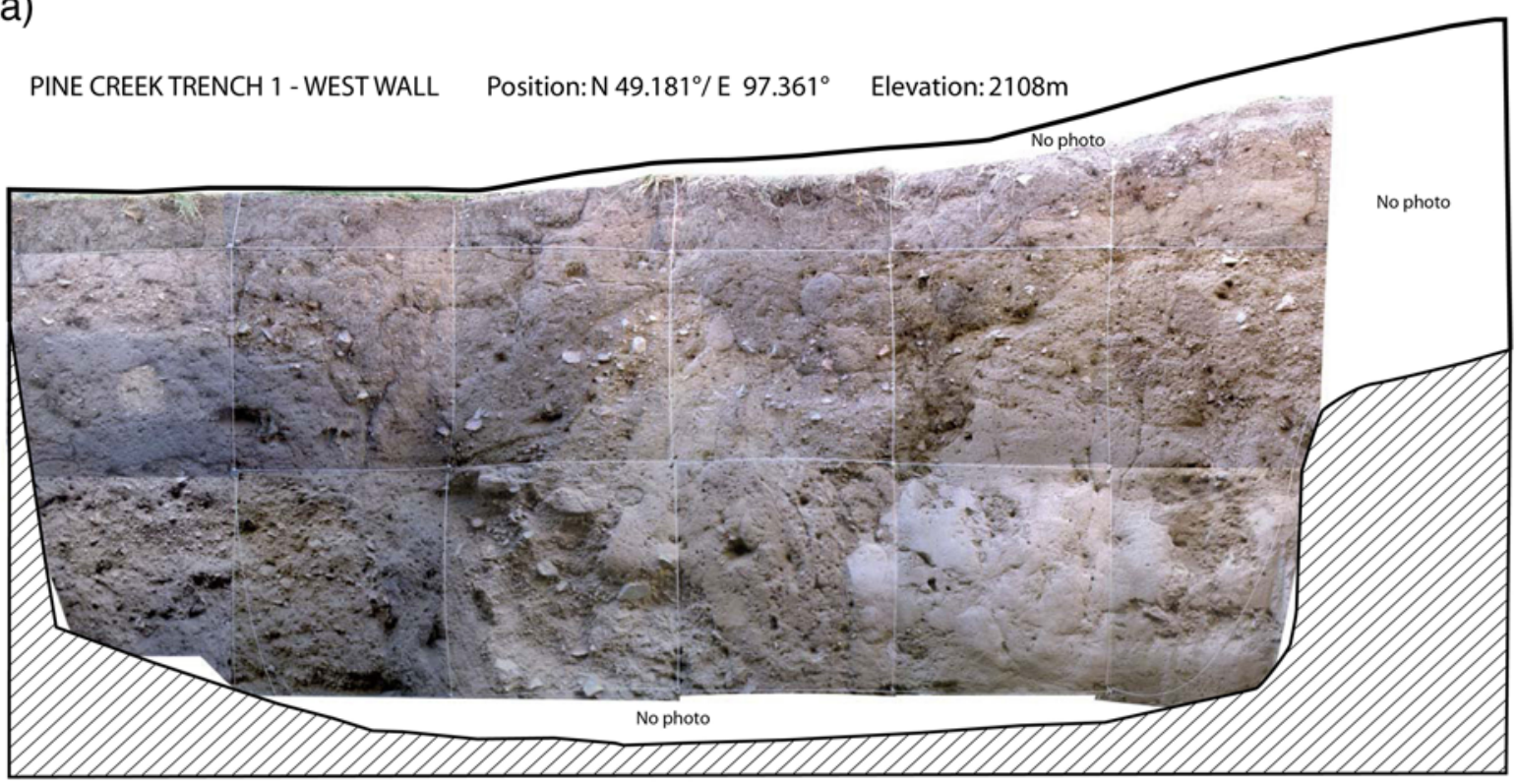

(b)

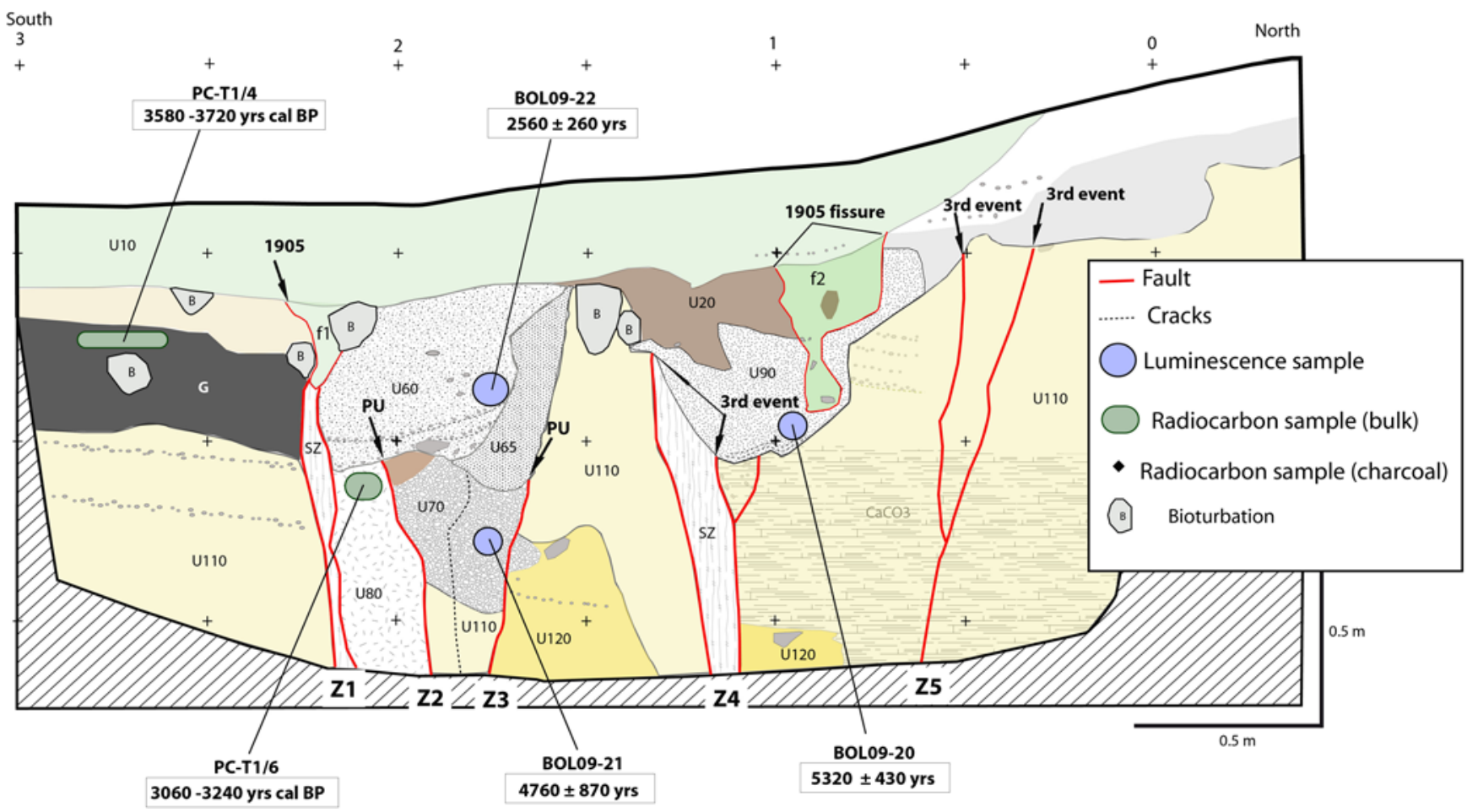

Figure 14. (a) Photomosaic of the west wall of T1. (b) Log of the west wall of Pine Creek trench 1 . The string grid is $0.5 \mathrm{~m}^{2}$. See Table 3 for stratigraphic description of the different units. PU indicates the penultimate event. The color version of this figure is available only in the electronic edition.

\section{Age of the S1 Surface}

The alluvial fan stratigraphy exposed in the soil pit excavated into $\mathrm{S} 1$ is comprised of two fine sand units interbedded with alluvial gravels (Fig. 9d). We collected sample BOL09-OSL11 at $45 \mathrm{~cm}$ depth within the sandy matrix of unit 1 . Using the IRSL technique, we determined an age of $6360 \pm 530 \mathrm{yr}$ after applying a fading correction of $6 \pm 0.5 \%$, following Auclair et al. (2003) and Huntley and Lamothe (2001) (Table 2; Fig. 9d). This age is consistent with the age of sample PC-T1-1 collected from the fissure fill composed of reworked alluvial fan unit 110, exposed in the trench and dated using radiocarbon at $8540-8770 \mathrm{cal}$ B.P. (Table 4). 


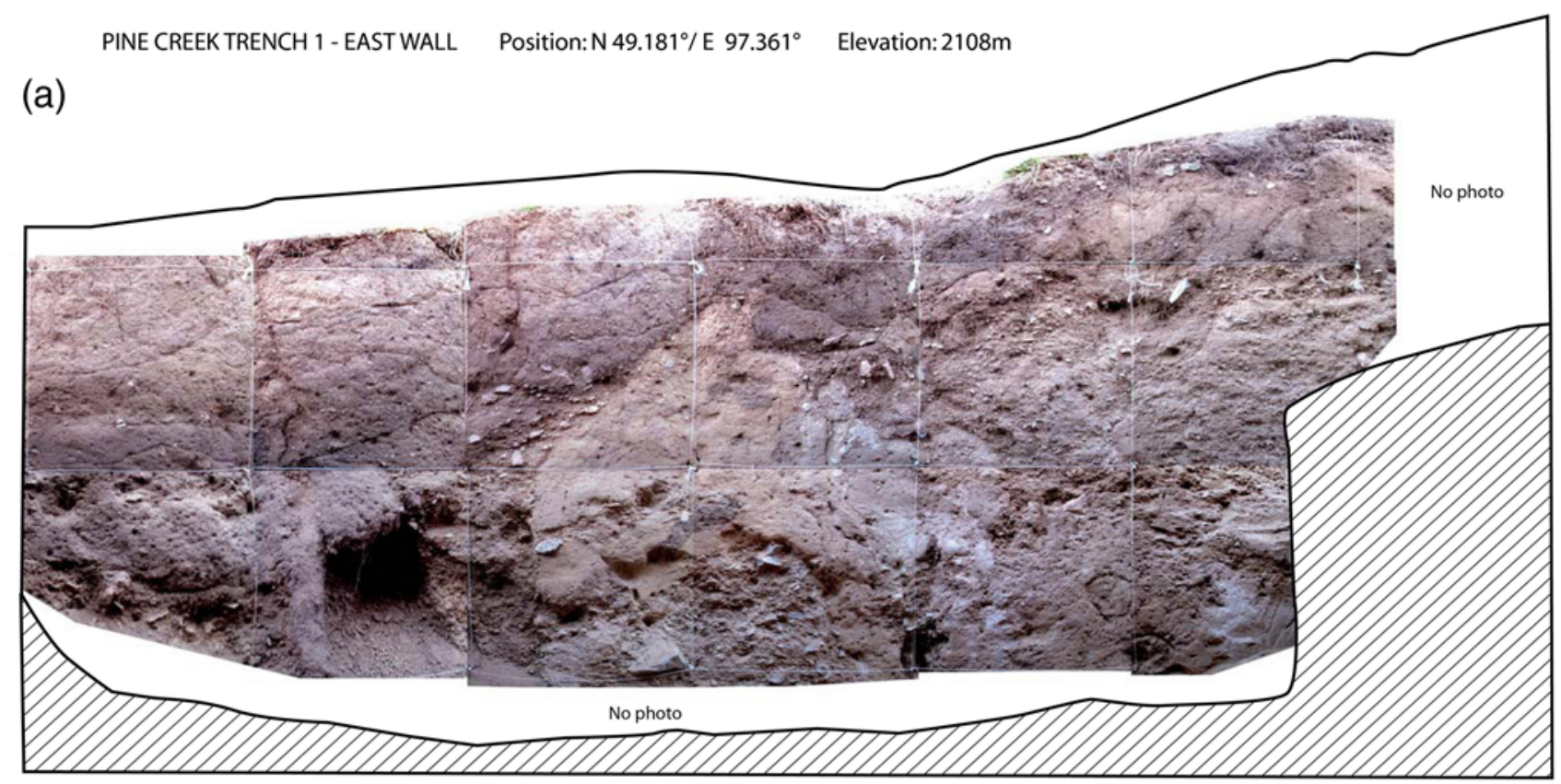

(b)

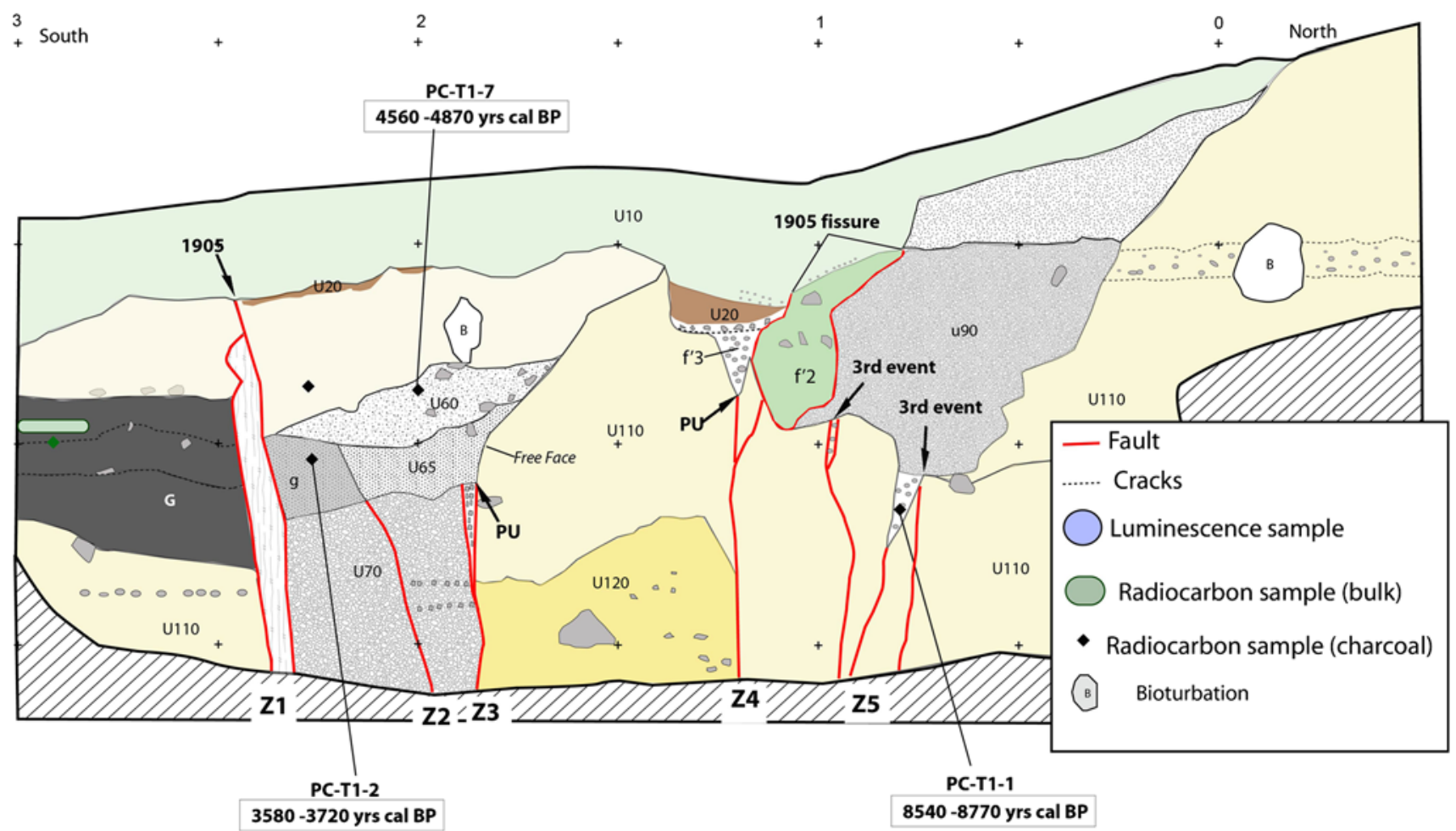

Figure 15. (a) Photomosaic of the east wall of T1. (b) Log of the east wall of Pine Creek trench 1 . The string grid is $0.5 \mathrm{~m}^{2}$. See Table 3 for stratigraphic description of the different units. PU indicates the penultimate event. The color version of this figure is available only in the electronic edition.

Summary of Pine Creek Earthquake and Sedimentary Chronology

Our observations combined with the luminescence and radiocarbon ages from both walls indicate that an earthquake occurred during the late stages of alluvial fan accumulation, about 5000-9000 yrs ago. The fan surface was subsequently abandoned and incised, and channel unit 90 was deposited about 5300 yrs ago. Additional incision occurred and the gravels of unit 70 were deposited approximately at $4800 \mathrm{yrs}$ ago. Another earthquake occurred, offsetting this channel, 
Table 3

Stratigraphic descriptions for Units Logged in the Trench at Pine Creek Site

\begin{tabular}{|c|c|}
\hline Unit & Description of Stratigraphy \\
\hline U10 & $\begin{array}{l}\text { Dark colored organic-rich silt matrix with unsorted } \\
\text { subrounded pebbles up to } 1 \mathrm{~cm}\end{array}$ \\
\hline $\mathrm{U} 20$ & $\begin{array}{l}\text { Black organic soil, expected to be the ground surface before } \\
\text { the } 1905 \text { event }\end{array}$ \\
\hline G & Dark gray organic-rich sand-silt matrix with few pebbles \\
\hline $\mathrm{g}$ & $\begin{array}{l}\text { Dark organic-rich layer; could correspond to the penultimate } \\
\text { ground surface }\end{array}$ \\
\hline U60 & Gray unsorted silt-sand matrix with clasts up to $5 \mathrm{~cm}$, channel \\
\hline U65 & $\begin{array}{l}\text { Unsorted sand matrix with subrounded pebbles up to } 6 \mathrm{~cm} \text {, } \\
\text { channel }\end{array}$ \\
\hline U70 & $\begin{array}{l}\text { Loose clast-supported matrix with angular to subrounded } \\
\text { clasts up to } 3 \mathrm{~cm}\end{array}$ \\
\hline U80 & $\begin{array}{l}\text { Yellowish very loose clast-supported matrix with subrounded } \\
\text { pebbles }\end{array}$ \\
\hline U90 & Sand matrix with subrounded pebbles up to $3 \mathrm{~cm}$, channel \\
\hline U100 & $\begin{array}{l}\text { Medium to coarse sand matrix with angular to subangular } \\
\text { clasts up to } 3 \mathrm{~cm} \text {, stratified, horizontal bedding, alluvial fan }\end{array}$ \\
\hline U110 & $\begin{array}{l}\text { Fine to medium sand matrix interbedded with sand-pebbly } \\
\text { matrix, rare pebbles, stratified, with horizontal bedding, } \\
\text { carbonate, alluvial fan }\end{array}$ \\
\hline $\mathrm{U} 120$ & $\begin{array}{l}\text { Fine to medium sand matrix with subangular pebbles up to } \\
5 \mathrm{~cm} \text { and few clasts up to } 15 \mathrm{~cm} \text {, stratified, horizontal } \\
\text { bedding, alluvial fan }\end{array}$ \\
\hline
\end{tabular}

between $2300 \mathrm{yr}$ and $3250 \mathrm{cal}$ B.P. Subsequently, channel units 65 and 60 formed and were offset during the 1905 earthquake.

The time interval between the 1905 earthquake and the penultimate earthquake is estimated to be $2750 \pm 450 \mathrm{yrs}$, and the interval between the penultimate earthquake and the third event is estimated to be $4100 \pm 2400 \mathrm{yrs}$. These two recurrence intervals overlap within their uncertainties and suggest that the most recent two recurrence intervals for large earthquakes on the Bulnay fault are generally on the order of $2700-4000$ yrs.

\section{Discussion and Conclusions}

In this article, we provide original data and basic information on a fault system that produced one of the largest historically recorded intracontinental earthquakes. Our study shows that the 23 July $1905\left(M_{\mathrm{w}} 8.3-8.5\right)$ Bulnay earthquake produced wide zones of deformation ranging from a few meters to a few hundred meters wide, defining one of the most outstanding ground surface ruptures associated with strike- slip faulting. Along the section of the fault between $97.18^{\circ} \mathrm{E}$ and $98.33^{\circ} \mathrm{E}$, we observed that the 1905 horizontal coseismic slip remains constant with a mean value of $8.9 \pm 0.6 \mathrm{~m}$. This is smaller than the $\sim 11 \mathrm{~m}$ reported by Khil'ko et al. (1985) and Baljynniam et al. (1993) and consistent with measurements made by Schwartz et al. (2009).

We also observed cumulative offsets that are twice that of the 1905 earthquake (mean value of $17 \pm 1.5 \mathrm{~m}$ ). Combined with our paleoseismological investigations, these features show that the two last events along the Bulnay fault (1905 and penultimate events) have similar slip. At Pine Creek for instance, we clearly observed two surface rupturing events postdating channel deposits associated with an incised stream that is offset $18 \mathrm{~m}$. This observation suggests that the distribution of slip along the Bulnay fault was at least similar for the two past earthquakes, as has been observed along the left-lateral strike-slip Bogd fault in the Gobi-Altay (Kurushin et al., 1998; Ritz et al., 2006; Rizza et al., 2011), along the right-lateral, strike-slip Fuyun fault in the Chinese Altay (Klinger et al., 2011), and along other large strike-slip faults worldwide (Schwartz and Coppersmith, 1984; Rubin and Sieh, 1997; Klinger et al., 2003; Haibing et al., 2005).

We calculated a mean horizontal slip rate along the Bulnay fault between $97.18^{\circ} \mathrm{E}$ and $98.33^{\circ} \mathrm{E}$ of $3.1 \pm 1.7 \mathrm{~mm} / \mathrm{yr}$ for the Upper Pleistocene-Holocene period. This is consistent with the strain accumulation of $2.6 \pm 1.0 \mathrm{~mm} / \mathrm{yr}$ estimated from GPS data by Calais et al. (2003). If we assume that the $\sim 3.1 \mathrm{~mm} / \mathrm{yr}$ slip rate has been constant over a longer period of time, the $\sim 4 \mathrm{~km}$ of total leftlateral displacement recorded along the fault (within the Yambi Mountains) would have been generated during the past $\sim 1.3 \mathrm{Ma}$. This age is in agreement with the onset of the reactivation of the Jid and Har-Us-Nuur faults in the Altay, estimated between $\sim 1$ and $\sim 2 \mathrm{Ma}$ (Walker et al., 2006; Nissen, Walker, Bayasgalan, et al., 2009).

Our study along the Bulnay fault was an opportunity to compare the OSL and ${ }^{10} \mathrm{Be}$ dating techniques in northern Mongolia, a cold, arid, intracontinental environment with relatively slow rates of tectonic activity. Our (E) results obtained with

${ }^{10} \mathrm{Be}$ (see electronic supplement) suggest that the drainage networks in the area are complex and the sources of fluvial sediments may have varied in time. A parameter that can vary is the temporal stream power (varies with climate) that produces rapid and short changes in the catchment erosion rates and in the transport rates. This may be clearly seen in some cases when concentration of ${ }^{10} \mathrm{Be}$ in active river sediments is higher

Table 4

Radiocarbon Ages at Pine Creek Site Using the Calib Radiocarbon Calibration Program (Reimer et al., 2009)

\begin{tabular}{cllll}
\hline Samples ID & \multicolumn{1}{c}{ Material } & Ages B.P. & Ages cal B.P. & \multicolumn{1}{c}{ Reason of collect } \\
\hline PC-T1-1 & Charcoal in unit 110, east wall & $7845 \pm 40$ & $8660 \pm 115$ & Age of alluvial fan, predating the third event \\
PC-T1-2 & Charcoal in unit $g$, east wall & $3955 \pm 30$ & $4400 \pm 50$ & Predating the penultimate event \\
PC-T1-4 & Charcoal in unit G, west wall & $3415 \pm 30$ & $3650 \pm 70$ & Predating the penultimate event \\
PC-T1-6 & Charcoal in unit 80, west wall & $2965 \pm 30$ & $3150 \pm 90$ & Predating the penultimate event \\
PC-T1-7 & Charcoal in unit 60, east wall & $4240 \pm 35$ & $4830 \pm 20$ & Postdating the penultimate event \\
\hline
\end{tabular}


than in older sediments (i.e., Genepi, Snow Creek sites) or when comparing sand and cobbles in the same pit (i.e., Armoise site). In addition, the alluvial surfaces typically are underlain by multilayered depositional formations that record successive exposure episodes, which makes the application of in situ produced cosmogenic isotopes very difficult. However, the two geochronometers are consistent together, in a first order, but rates of the surface processes (erosion, transport) and ${ }^{10} \mathrm{Be}$ concentrations only allow determination of minimum age or inheritance when the alluvium have experienced short exposure times, making luminescence methods favorable for a more precise dating (good resetting, fine material, etc.).

From our paleoseismological study at Pine Creek, we determined that the last two interseismic periods between great earthquakes along the Bulnay fault are of the order of 2700-4000 yrs. This is consistent with the mean time interval (i.e., $\sim 2900$ yrs) estimated by dividing the mean 1905 offset $(\sim 9 \mathrm{~m})$ by the mean long term slip rate $(\sim 3.1 \mathrm{~mm} / \mathrm{yr})$ and suggests that past earthquakes along the Bulnay fault have magnitudes similar to that of the 1905 earthquake.

Finally, when compared to the mean $\sim 3000-5000 \mathrm{yr}$ earthquake recurrence obtained from morphotectonics and paleoseismological studies along the Bogd fault system in Gobi-Altay (Ritz et al., 1995; Schwartz et al., 1996, 2007; Prentice et al., 2002; Rizza et al., 2008, 2011), our results suggest that the seismic cluster that occurred during the twentieth century in Mongolia is similar to a seismic cluster that occurred 3000-4000 yrs ago and is likely typical of fault behavior in this region. This observation raises the questions of whether large earthquakes may have triggered other large earthquakes in an apparently dormant zone, even if faults are separated by several hundred kilometers, and what physical parameters control fault behaviors. The idea of earthquake clusters in Mongolia has already been explored by numerical modeling of postseismic stress relaxation of the lithosphere after large earthquakes (Chéry et al., 2001; Pollitz et al., 2003). These articles show that viscoelastic and elastic stress transfer could be responsible for earthquake time clustering, on timescales of decades, along continental faults separated by hundreds kilometers. These preliminary results were based on assumptions of mean recurrence times of thousands of years. In the context of testing models of stress triggering among continental earthquakes (long distance and long time), our preliminary study along the Bulnay fault is important evidence showing that similar earthquake sequences to those that were recorded between 1905 and 1957 may have previously struck the area in past millennia. However, further studies are needed to determine whether past surface ruptures have the same age elsewhere along the Bulnay fault, in the Gobi and Altay ranges.

\section{Data and Resources}

The Global Centroid Moment Tensor Project database was searched using www.globalcmt.org/CMTsearch.html (last accessed January 2014).
The Google Earth views are from http://www.google .com/earth (last accessed January 2014), and fault mapping was done using the Open Source Quantum GIS software version 1.8 (http://www.qgis.org/; last accessed January 2014).

The ASTER global digital elevation models were obtained from http://www.jspacesystems.or.jp/ersdac/GDEM/ E/4.html (last accessed November 2011).

\section{Acknowledgments}

This work was supported by the French INSU 3F 2009 program and by the Observatoire des Sciences de l'Univers (OSU) Observatoire de REcherche Méditerranéen de l'Environnement (OREME) in Montpellier. SPOT-5 imagery has been acquired with the Incitation à l'utilisation Scientifique des Images SPOT (ISIS)/Centre National d'Etudes Spatiales (CNES) number 101 program. ASTER Team members (M. Arnold, G. Aumaitre, D. Bourlès, and K. Keddadouche) are thanked for their valuable assistance during ${ }^{10} \mathrm{Be}$ measurements at the Accélérateur pour les Sciences de la Terre, Environnement, Risques (ASTER) national facility (Centre Européen de Recherche et d'Enseignement de Géosciences de l'Environnement [CEREGE], Aix en Provence), which is supported by the Institut National des Sciences de l'Univers (INSU)/Centre National de la Recherche Scientifique (CNRS), the French Ministry of Research and Higher Education, Institut de Recherche pour le Développement (IRD) and Commissariat à l'Energie Atomique (CEA). In this project, carbon-14 $\left({ }^{14} \mathrm{C}\right)$ measurements were performed in the framework of the Accélérateur pour la Recherche en sciences de la Terre, Environnement et Muséologie (ARTEMIS)/INSU service. We would like to acknowledge our drivers and cook for the technical support during the field. We thank David Schwartz for providing us aerial photographs and suggestions for paleoseismological sites and for fruitful discussions. We are grateful to Sally McGill, Ryan Gold, Kate Scharer, and an anonymous reviewer for their constructive comments and their help to improve the manuscript.

\section{References}

Aitken, M. J. (1998). An Introduction to Optical Dating: The Dating of Quaternary Sediments by the Use of Photon-Stimulated Luminescence, Academic Press, London.

Auclair, M., M. Lamothe, and S. Huot (2003). Measurement of anomalous fading for feldspar IRSL using SAR, Radiat. Meas. 37, 487-492.

Baljinnyam, I., A. Bayasgalan, B. A. Borisov, A. Cisternas, M. G. Dem'yanovich, L. Ganbaatar, V. M. Kochetkov, R. A. Kurushin, P. Molnar, H. Philip, and Y. Vashchilov (1993). Ruptures of major earthquakes and active deformation in Mongolia and its surroundings, Geol. Soc. Am. Memoir 181, 61.

Braucher, R., D. L. Bourles, F. Colin, J. Oliveira, and A. B. Vecchieto (1998). Use of in situ-produced cosmogenic (super 10) Be for the study of Brazilian lateritic soil evolution, Mineral. Mag. 62A, Part 1, 233-234.

Braucher, R., S. Merchel, J. Borgomano, and D. Bourlès (2011). Production of cosmogenic radionuclides at great depth: A multi element approach, Earth Planet. Sci. Lett. 309, 1-9, doi: 10.1016/j.epsl.2011.06.036.

Calais, E., M. Vergnolle, V. San'kov, A. Lukhnev, A. Miroshnitenko, S. Amarjargal, and J. Déverchère (2003). GPS measurements of crustal deformation in the Baikal-Mongolia area (1994-2002): Implications for current kinematics of Asia, J. Geophys. Res. 108, 2501-2514.

Chéry, J., S. Carretier, and J.-F. Ritz (2001). Postseismic stress transfer explains time clustering of large earthquakes in Mongolia, Earth Planet. Sci. Lett. 194, 277-286.

Cunningham, D. (2007). Structural and topographic characteristics of restraining bend mountain ranges of the Altai, Gobi Altai and easternmost Tien Shan, Geol. Soc. Lond. Spec. Publ. 290, 219-237, doi: 10.1144/SP290.7. 
Cunningham, W. D. (1998). Lithospheric controls on late Cenozoic construction of the Mongolian Altai, Tectonics 17, 891-902, doi: 10.1029/1998TC900001.

Florensov, N. A. and V. P. Solonenko (Editors) (1965). The Gobi-Altai Earthquake, U.S. Department of Commerce, Washington, D.C., 424 pp.

Haibing, L., J. van der Woerd, P. Tapponnier, Y. Klinger, X. Qi, J. Yang, and Y. Zhu (2005). Slip rate on the Kunlun fault at Hongshui Gou, and recurrence time of great events comparable to the 14/11/2001, $M_{\mathrm{w}}$ approximately 7.9 Kokoxili earthquake, Earth Planet. Sci. Lett. 237, 285-299.

Huntley, D. J., and M. Lamothe (2001). Ubiquity of anomalous fading in $\mathrm{K}$-feldspars and the measurement and correction for it in optical dating, Can. J. Earth Sci. 38, 1093-1106.

Khil'ko, S. D., R. A. Kurushin, V. M. Kochetkov, L. A. Misharina, V. I. Mel'nikova, N. A. Gileva, S. V. Lastochkin, I. Balzhinnyam, and D. Monkhoo (1985). Earthquakes and the Bases of the Seismic Zoning of Mongolia, in The Joint Soviet-Mongolian Scientific Research Geological Expedition, Vol. 41, 225 pp.

Klinger, Y., M. Etchebes, P. Tapponnier, and C. Narteau (2011). Characteristic slip for five great earthquakes on the Fuyun fault in China, Nat. Geosci. 4, 389-392, doi: 10.1038/ngeo1158.

Klinger, Y., K. Sieh, E. Altunel, A. Akoglu, A. A. Barka, T. E. Dawson, T. Gonzalez, A. J. Meltzner, and T. K. Rockwell (2003). Paleoseismic evidence of characteristic slip on the western segment of the North Anatolian fault, Turkey, Bull. Seismol. Soc. Am. 93, 2317-2332.

Kurushin, R. A., A. Bayasgalan, M. Olziybat, B. Enhtuvshin, P. Molnar, C. Bayarsayhan, K. W. Hudnut, and J. Lin (1998). The surface rupture of the 1957 Gobi-Altay, Mongolia, earthquake, Geol. Soc. Am. Spec. Pap. 320, 144, doi: 10.1130/0-8137-2320-5.1.

Lang, A. (1994). Infra-red stimulated luminescence dating of Holocene reworked silty sediments, Quaternary Sci. Rev. 13, 525-528.

LeDortz, K., B. Meyer, M. Sébrier, H. Nazari, R. Braucher, M. Fattahi, L. Benedetti, M. Foroutan, L. Siame, D. Bourlès, et al. (2009). Holocene right-slip rate determined by cosmogenic and OSL dating on the Anar fault, central Iran, Geophys. J. Int. 179, 700-710.

Molnar, P., and Q. Deng (1984). Faulting associated with large earthquakes and the average rate of deformation in central and eastern Asia, J. Geophys. Res. 89, 6203-6227.

Molnar, P., and P. Tapponnier (1977). The collision between India and Eurasia, Sci. Am. 236, 30-41.

Murray, A. S., R. Marten, A. Johnson, and P. Martin (1987). Analysis for naturally occurring radionuclides at environmental concentrations by gamma spectrometry, J. Radioanal. Nucl. Chem. 115, 263-288.

Nissen, E., R. T. Walker, A. Bayasgalan, A. Carter, M. Fattahi, E. Molor, C. Schnabel, A. J. West, and S. Xu (2009). The late Quaternary slip-rate of the Har-Us-Nuur Fault (Mongolian Altai) from cosmogenic (super 10) Be and luminescence dating, Earth Planet. Sci. Lett. 286, 467-478.

Nissen, E., R. Walker, E. Molor, M. Fattahi, and A. Bayasgalan (2009). Late Quaternary rates of uplift and shortening at Baatar Hyarhan (Mongolian Altai) with optically stimulated luminescence, Geophys. J. Int. 177, 259-278.

Okal, E. A. (1976). A surface-wave investigation of the rupture mechanism of the Gobi-Altai (December 4, 1957) earthquake, Phys. Earth Planet. Int. 12, 319-328.

Pollitz, F., M. Vergnolle, and E. Calais (2003). Fault interaction and stress triggering of twentieth century earthquakes in Mongolia, J. Geophys. Res. 108, 14.

Prentice, C. S., K. Kendrick, K. Berryman, A. Bayasgalan, J.-F. Ritz, and J. Q. Spencer (2002). Prehistoric ruptures of the Gurvan Bulag fault, Gobi Altay, Mongolia, J. Geophys. Res. 107, 2321-2339.

Prescott, J. R., and J. T. Hutton (1994). Cosmic-ray contributions to doserates for luminescence and ESR dating-large depths and long-term time variations, Rad. Meas. 23, 497-500.

Reimer, P. J., M. G. L. Baillie, E. Bard, A. Bayliss, J. W. Beck, P. G. Blackwell, C. Bronk Ramsey, C. E. Buck, G. S. Burr, R. L. Edwards, et al.
(2009). IntCal09 and Marine09 radiocarbon age calibration curves, 0-50,000 years cal BP, Radiocarbon 51, 1111-1150.

Richardson, C. A., E. V. McDonald, and A. J. Busacca (1997). Luminescence dating of loess from the northwest United States, Quaternary Sci. Rev. 16, 403-415.

Ritz, J.-F., D. L. Bourlès, E. T. Brown, S. Carretier, J. Chéry, B. Enhtuvshin, P. Galsan, R. C. Finkel, T. C. Hanks, K. J. Kendrick, et al. (2003). Late Pleistocene to Holocene slip rates for the Gurvan Bulag thrust fault (Gobi-Altay, Mongolia) estimated with ${ }^{10} \mathrm{Be}$ dates, J. Geophys. Res. 108, 2162-2178.

Ritz, J.-F., E. T. Brown, D. L. Bourlès, H. Philip, A. Schlupp, G. M. Raisbeck, F. Yiou, and B. Enkhtuvshin (1995). Slip rates along active faults estimated with cosmic-ray-exposure dates: Application to the Bogd fault, Gobi-Altaï, Mongolia, Geology 23, 1019-1024.

Ritz, J.-F., R. Vassallo, R. Braucher, E. T. Brown, S. Carretier, and D. L. Bourlès (2006). Using in situ produced ${ }^{10} \mathrm{Be}$ to quantify active tectonics in the Gurvan Bogd mountain range (Gobi-Altay, Mongolia), Geol. Soc. Am. 415, 87-110.

Rizza, M. (2010). Analyses des vitesses et des déplacements co-sismiques sur des failles décrochantes en Mongolie et en Iran-Approche morphotectonique et paleosismologique, Ph.D. Thesis, Université Montpellier 2, 408 (in French).

Rizza, M., J.-F. Ritz, R. Braucher, R. Vassallo, C. Prentice, S. Mahan, S. McGill, A. Chauvet, S. Marco, M. Todbileg, et al. (2011). Slip rate and the slip magnitude of past earthquakes along the Bogd left-lateral strike-slip fault (Mongolia), Geophys. J. Int. 186, 897-927, doi: 10.1111/j.1365-246X.2011.05075.x.

Rizza, M., J.-F. Ritz, C. Prentice, R. Braucher, R. Vassallo, D. Schwartz, S. Marco, S. Mahan, M. Ulzibaat, M. Todbileg, et al. (2008). Age and slip distribution of past earthquakes along the Bogd fault (Mongolia), Eos Trans. AGU 89, abstract \#T21B-1959.

Rubin, C. M., and K. Sieh (1997). Long dormancy, low slip rate, and similar slip-per-event for the Emerson fault, eastern California shear zone, $J$. Geophys. Res. 102, 15,319-15,333.

Schlupp, A. (1996). Néotectonique de la Mongolie Occidentale analysée à partir de données de terrain, sismologiques et satellitaires, Ph.D. Thesis, University Louis Pasteur, Strasbourg, France, 172 pp.

Schlupp, A., and A. Cisternas (2007). Source history of the 1905 great Mongolian earthquakes (Tsetserleg, Bolnay), Geophys. J. Int. 169, $1115-1131$.

Schwartz, D. P., and K. J. Coppersmith (1984). Fault behavior and characteristic earthquakes: Examples from the Wasatch and San Andreas fault zones, J. Geophys. Res. 89, 5681-5698.

Schwartz, D. P., A. Bayasgalan, T. C. Hanks, K. Hanson, W. Lund, C. S. Prentice, J. F. Ritz, T. K. Rockwell, and K. Rockwell (2007). Paleoseismic investigations of the 1957 Gobi-Altay surface ruptures, 50th Anniversary Earthquake Conference Commemorating the 1957 Gobi-Altay Earthquake, Mongolia, Ulaanbaatar, Mongolia, July-August 2007.

Schwartz, D. P., T. C. Hanks, C. S. Prentice, A. Bayasgalan, J. F. Dolan, T. K. Rockwell, P. Molnar, and R. B. Hermann (1996). The 1957 Gobi-Altay earthquake $(\mathrm{M}=8.1)$; complex; long recurrence (?) interval faulting in the middle of a continent, Seismol. Res. Lett. 67, no. 2, 54.

Schwartz, D. P., S. Hecker, D. Ponti, H. Stenner, W. Lund, and A. Bayasgalan (2009). The July 23, 1905 Bulnay fault, Mongolia, surface rupture, Seismol. Res. Lett. 80, 357.

Sengör, A. M. C., B. A. Natal'in, and V. S. Burtman (1993). Evolution of the Altaid tectonic collage and Palaeozoic crustal growth in Eurasia, Nature 364, 299-307.

Siame, L., B. Regis, and D. Bourles (2004). Cosmic ray exposure modeling of concentration depth-profiles: Methodology and limitations, International Geological Congress, Abstracts (Congres Geologique International, Resumes) 32, Part 2, 923-924.

Singhvi, A. K., Y. P. Sharma, and D. P. Agrawal (1982). Thermoluminescence dating of sand dunes in Rajasthan, India, Nature 295, 313-314.

Tapponnier, P., and P. Molnar (1979). Active faulting and Cenozoic tectonics of the Tien Shan, Mongolia, and Baykal regions, J. Geophys. Res. 84, 3425-3459. 
Vassallo, R., J.-F. Ritz, R. Braucher, and S. Carretier (2005). Dating faulted alluvial fans with cosmogenic 10Be in the Gurvan Bogd mountain range (Gobi-Altay, Mongolia): Climatic and tectonic implications, Terra Nova 17, 278-285.

Vassallo, R., J.-F. Ritz, R. Braucher, M. Jolivet, S. Carretier, C. Larroque, A. Chauvet, C. Sue, M. Todbileg, D. Bourlès, et al. (2007). Transpressional tectonics and stream terraces of the Gobi-Altay, Mongolia, Tectonics 26, TC5013, doi: 10.1029/2006TC002081.

Vergnolle, M. (2003). Rhéologie et déformation de la lithosphère continentale: Apport de mesures GPS en Asie et de modèles numériques, Ph.D. Thesis, University Nice-Sophia Antipolis, Nice, France.

Vergnolle, M., F. Pollitz, and E. Calais (2003). Constraints on the viscosity of the continental crust and mantle from GPS measurements and postseismic deformation models in western Mongolia, J. Geophys. Res. 108, 14.

Voznesenskii, A. V. (1962). Investigations of the region of the Hangay earthquakes of 1905 in northern Mongolia, Materials from the Department of Physical geographical Society of the URSS, $50 \mathrm{pp}$. (in Russian).

Walker, R. T., A. Bayasgalan, R. Carson, R. Hazlett, L. McCarthy, J. Mischler, E. Molor, P. Sarantsetseg, L. Smith, B. Tsogtbadrakh, and G. Tsolmon (2006). Geomorphology and structure of the Jid rightlateral strike-slip fault in the Mongolian Altay Mountains, J. Struct. Geol. 28, 1607-1622.

Géosciences Montpellier-5243

Université Montpellier 2

Montpellier 34095, France

(M.R., J.-F.R.)

U.S. Geological Survey

MS 977

Menlo Park, California 94025

(C.P.)

ISTerre

5275

Université de Savoie

73376 Le Bourget du Lac, France

(R.V.)
Aix-Marseille Université

Centre Européen de Recherche et d'Enseignement de Géosciences de l'Environnement 7330

BP 80, 13545 Aix en Provence, France

(R.B., ASTER Team)

Géoazur-7329

Valbonne 06560, France

(C.L.)

Institute of Earth's Crust

Russian Academy of Sciences

Irkutsk 664033, Russia

(A.A., S.A.)

U.S. Geological Survey

MS 974

Denver, Colorado 80225

(S.M.)

Université Paris-Sud

91405 Orsay, France

(M.M., J.-L.M.)

Mongolian University of Science and Technology

P.O. Box 46/433Ulaanbaatar

210646, Mongolia

(M.T.) 